\title{
Isocyanide-Based Multicomponent Bicyclization with Substituted Allenoate and Isatin: Synthesis of Unusual Spirooxindole Containing [5.5]- Fused Heterocycle
}

Zhongzhong Tang, ${ }^{\dagger}$ Zhiqiang Liu, ${ }^{\dagger}$ Yu An,${ }^{\dagger}$ Ruolan Jiang, ${ }^{\dagger}$ Xinglu Zhang, ${ }^{\dagger}$ Chunju Li, ${ }^{\dagger}$ Xueshun Jia, ${ }^{*},{ }^{\dagger}$ and Jian $\mathrm{Li}^{*}, \dagger$

${ }^{\dagger}$ Department of Chemistry, Innovative Drug Research Center, Shanghai University, 99 Shangda Road, Shanghai 200444, P. R. China

¥ Shanghai Key Laboratory of High Temperature Superconductors, Shanghai University, Shanghai, 200444, P. R. China

E-mail: xsjia@mail.shu.edu.cn, lijian@ shu.edu.cn

\section{Table of Contents}

$1{ }^{1}$ H NMR and ${ }^{13} \mathrm{C}$ NMR Spectra of All Compounds

2 Crystal Structure of Compound 4d 


\section{$1{ }^{1} \mathrm{H}$ NMR and ${ }^{13} \mathrm{C}$ NMR Spectra of All Compounds}

Compound 4a
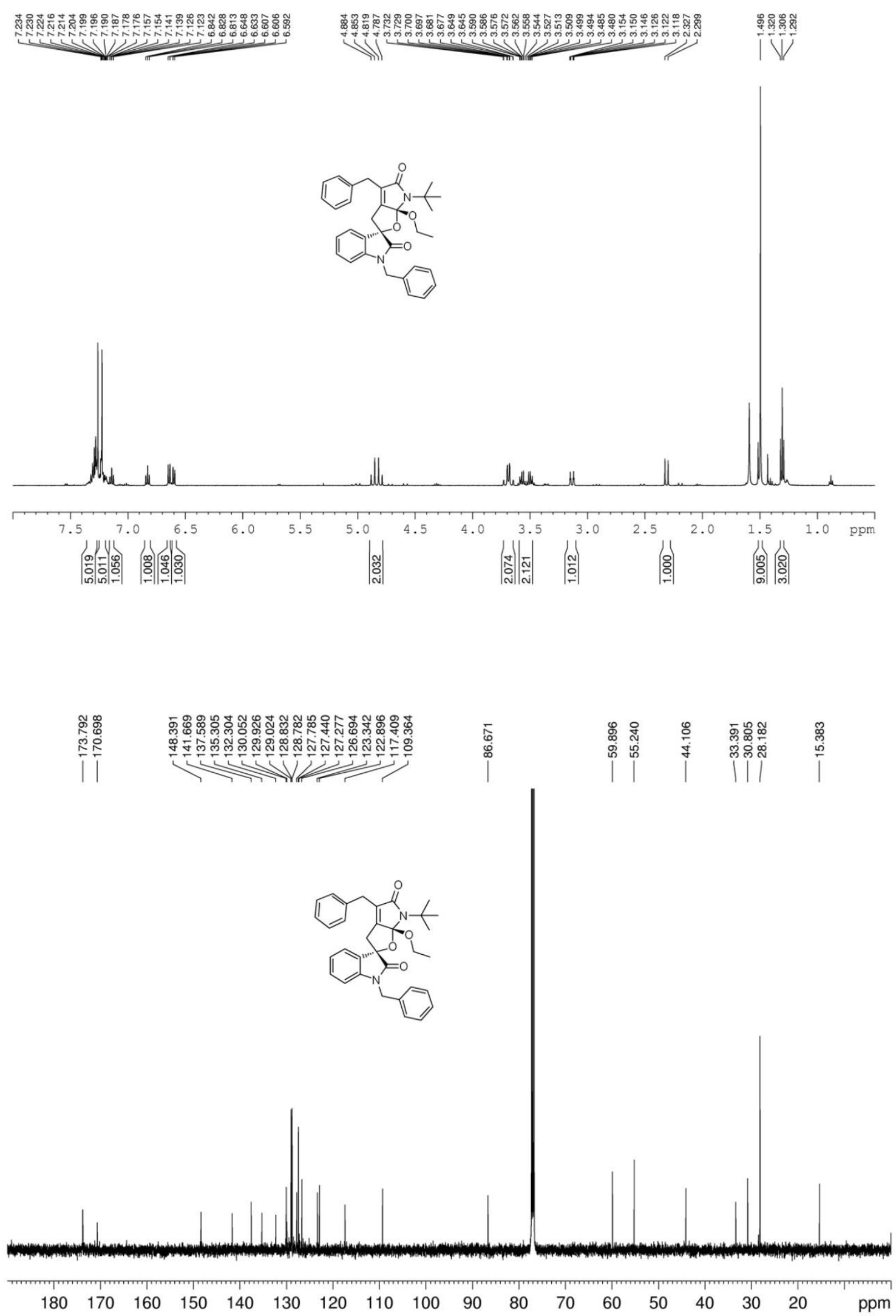


\section{Compound $\mathbf{4 b}$}

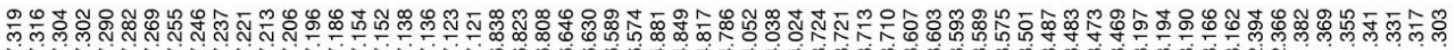

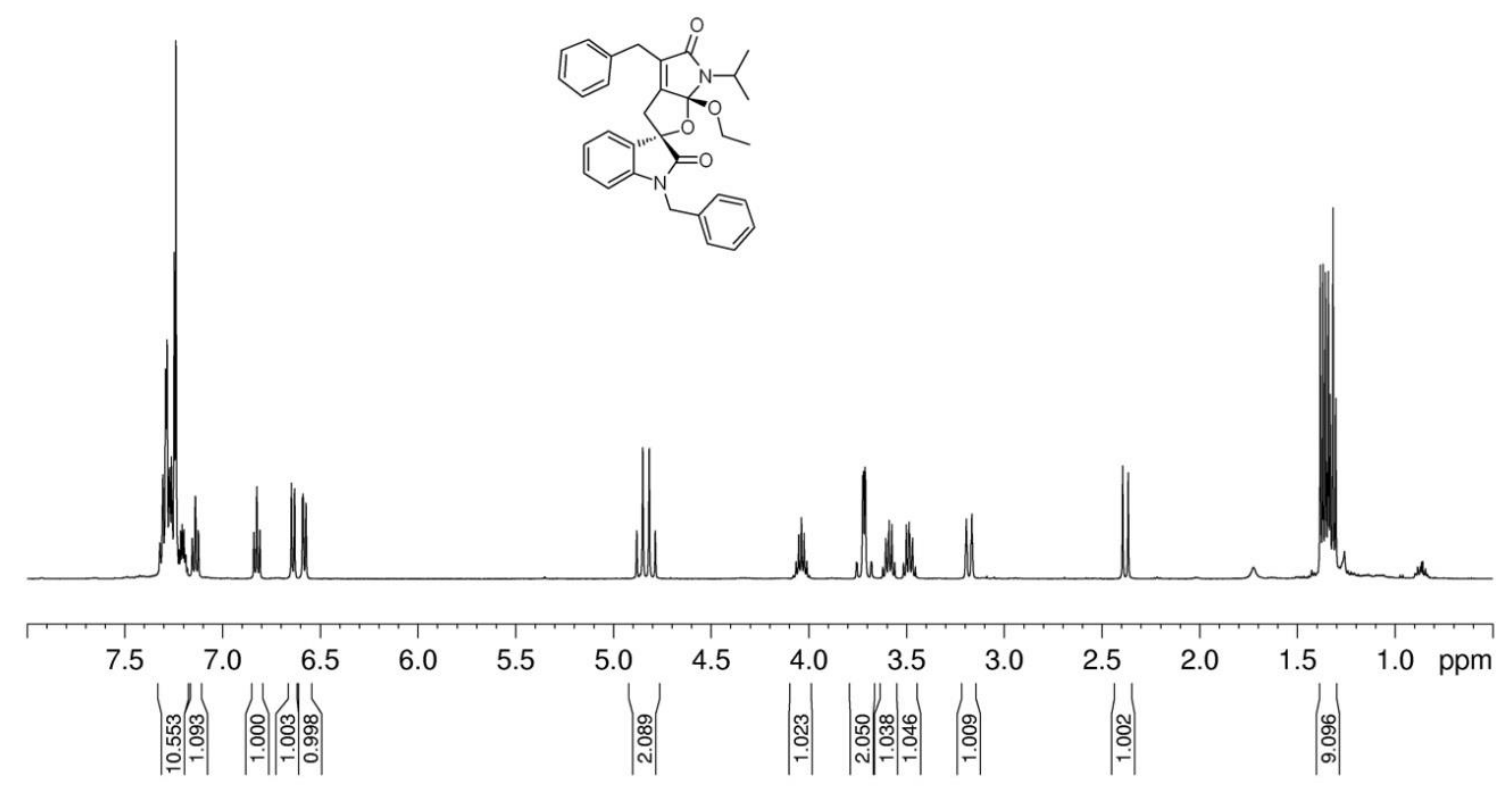

|l

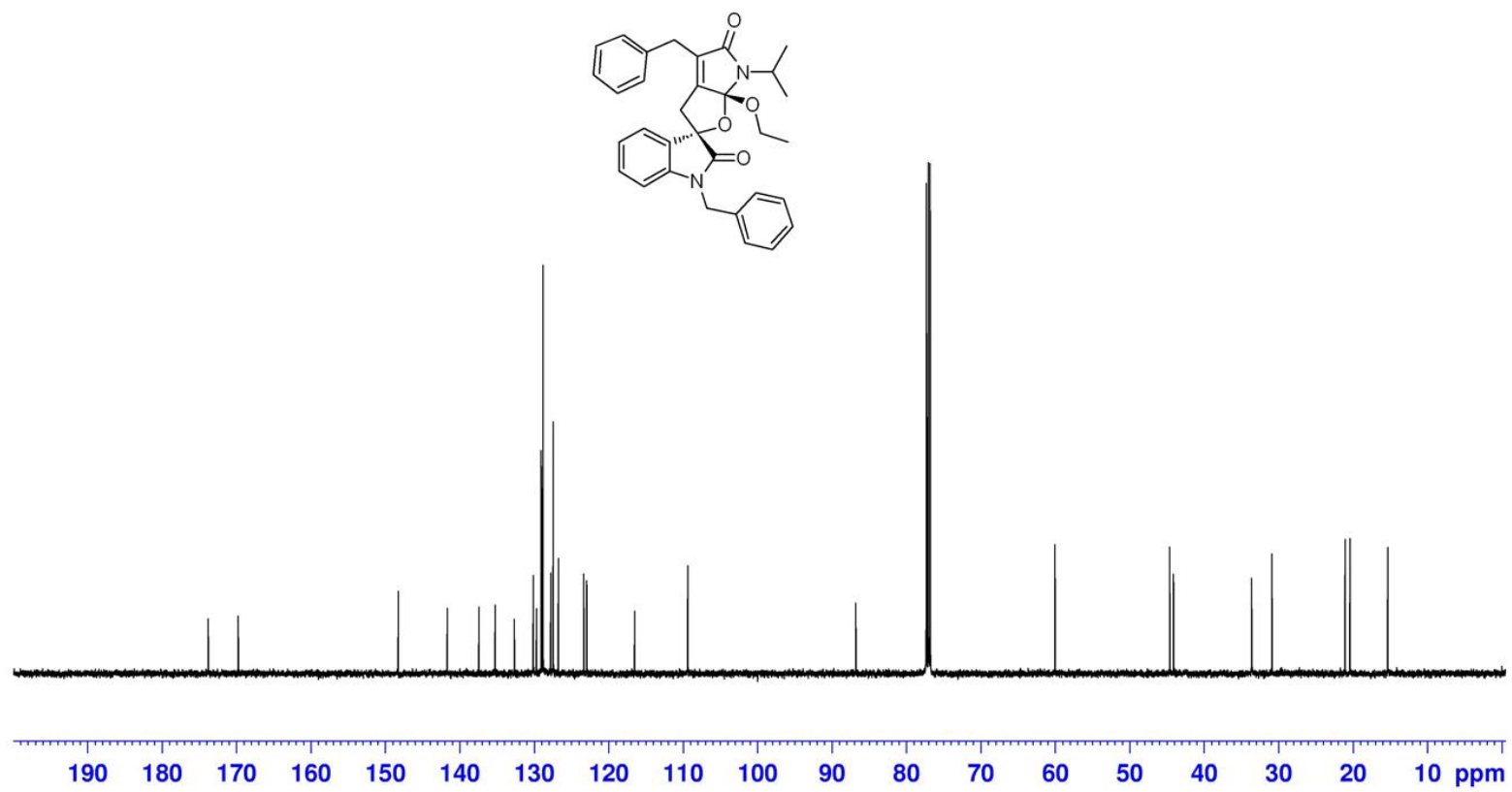




\section{Compound $\mathbf{4 c}$}

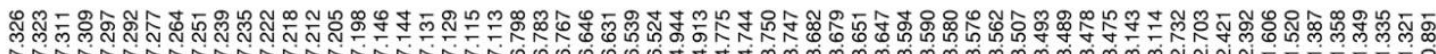

(n)
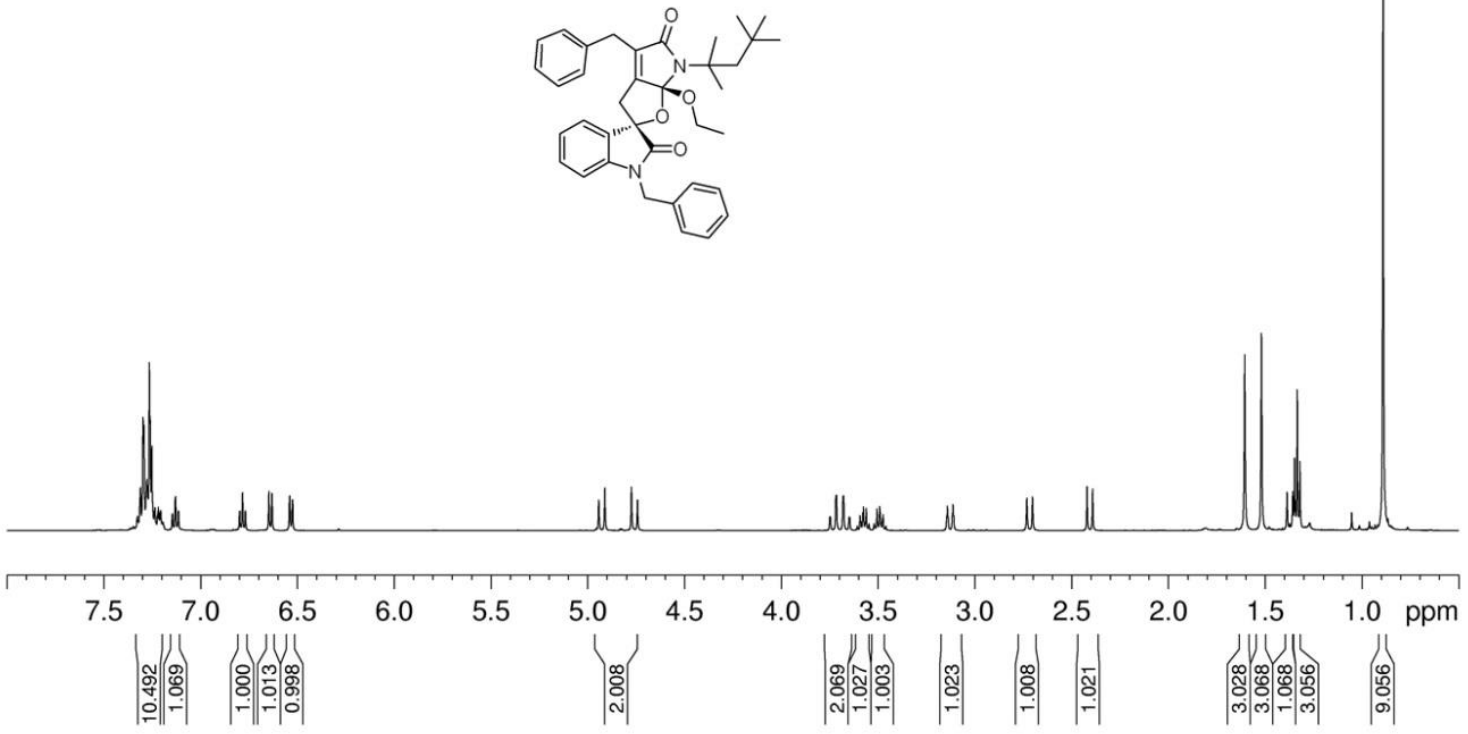

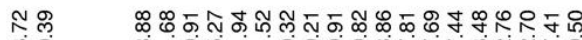

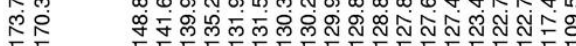

1
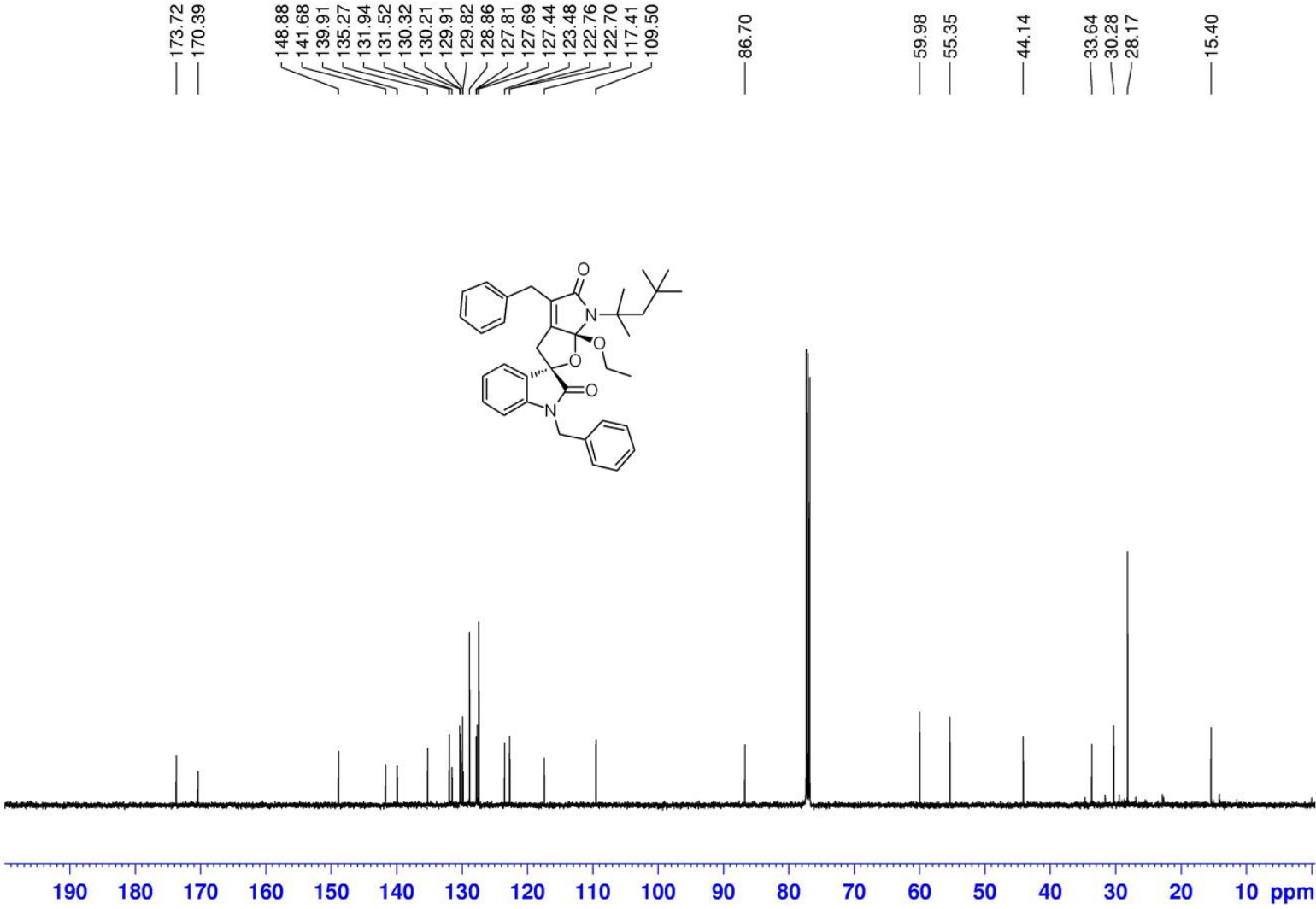


\section{Compound 4d}

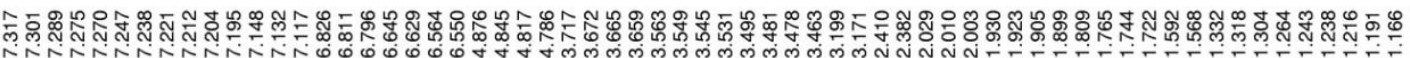

$1+1$

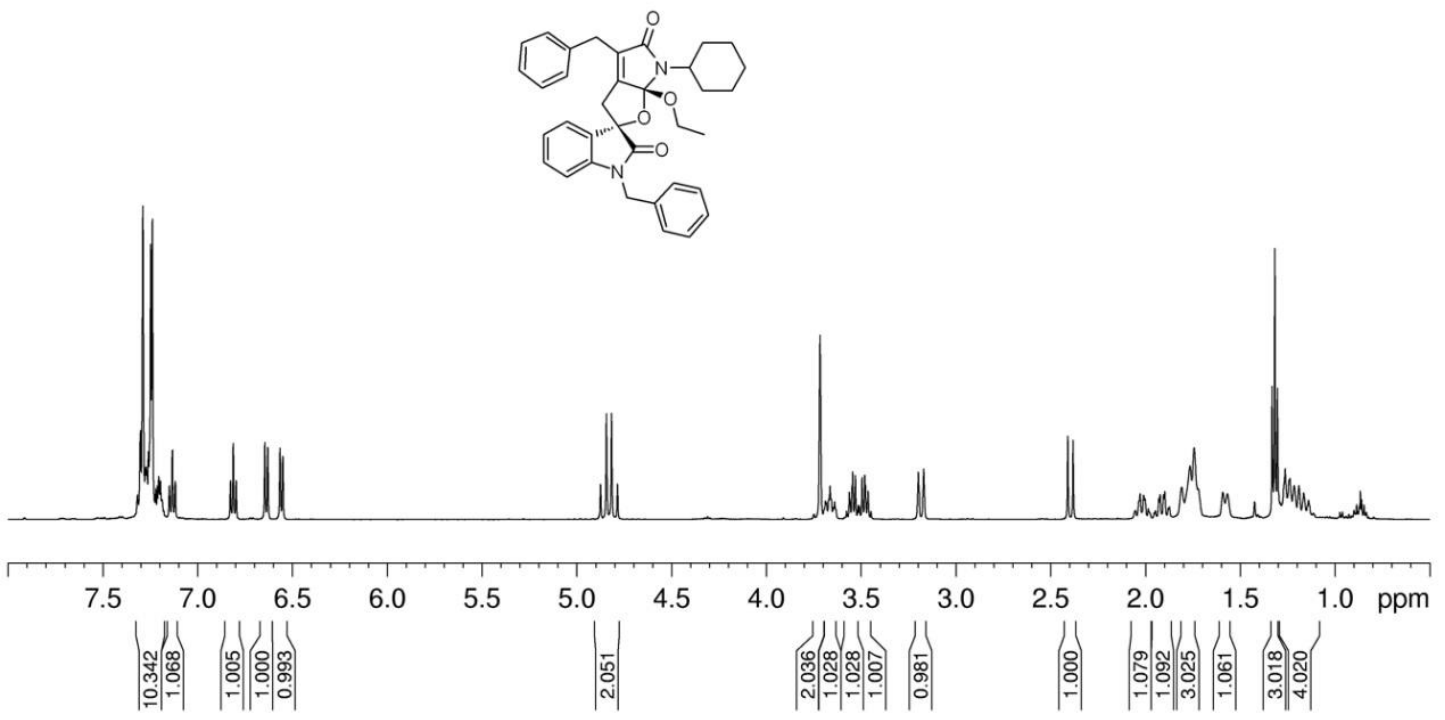

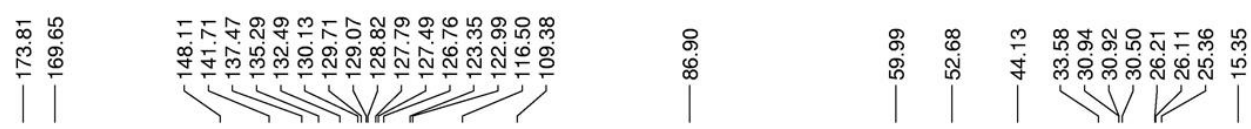

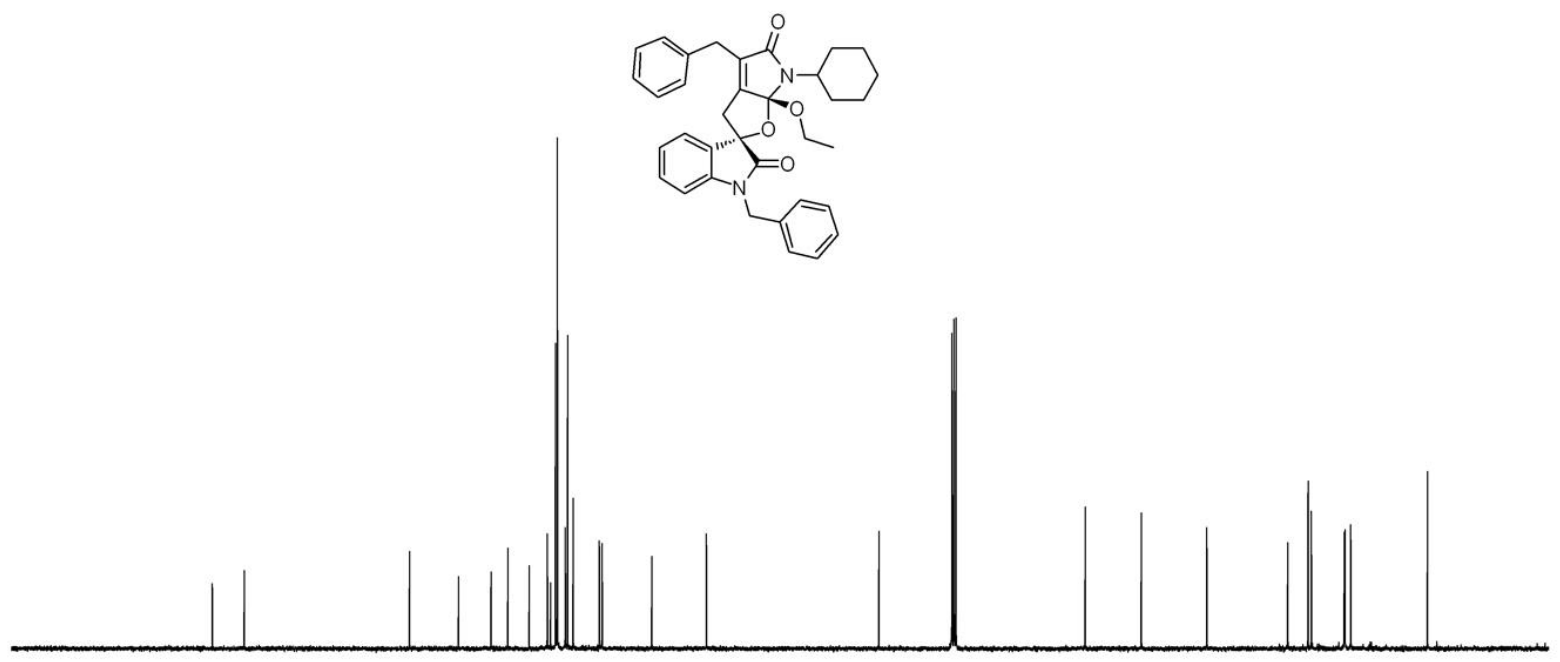

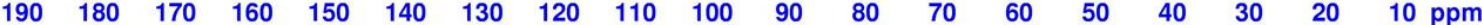




\section{Compound $4 \mathbf{e}$}

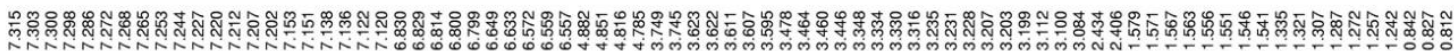
N N N N
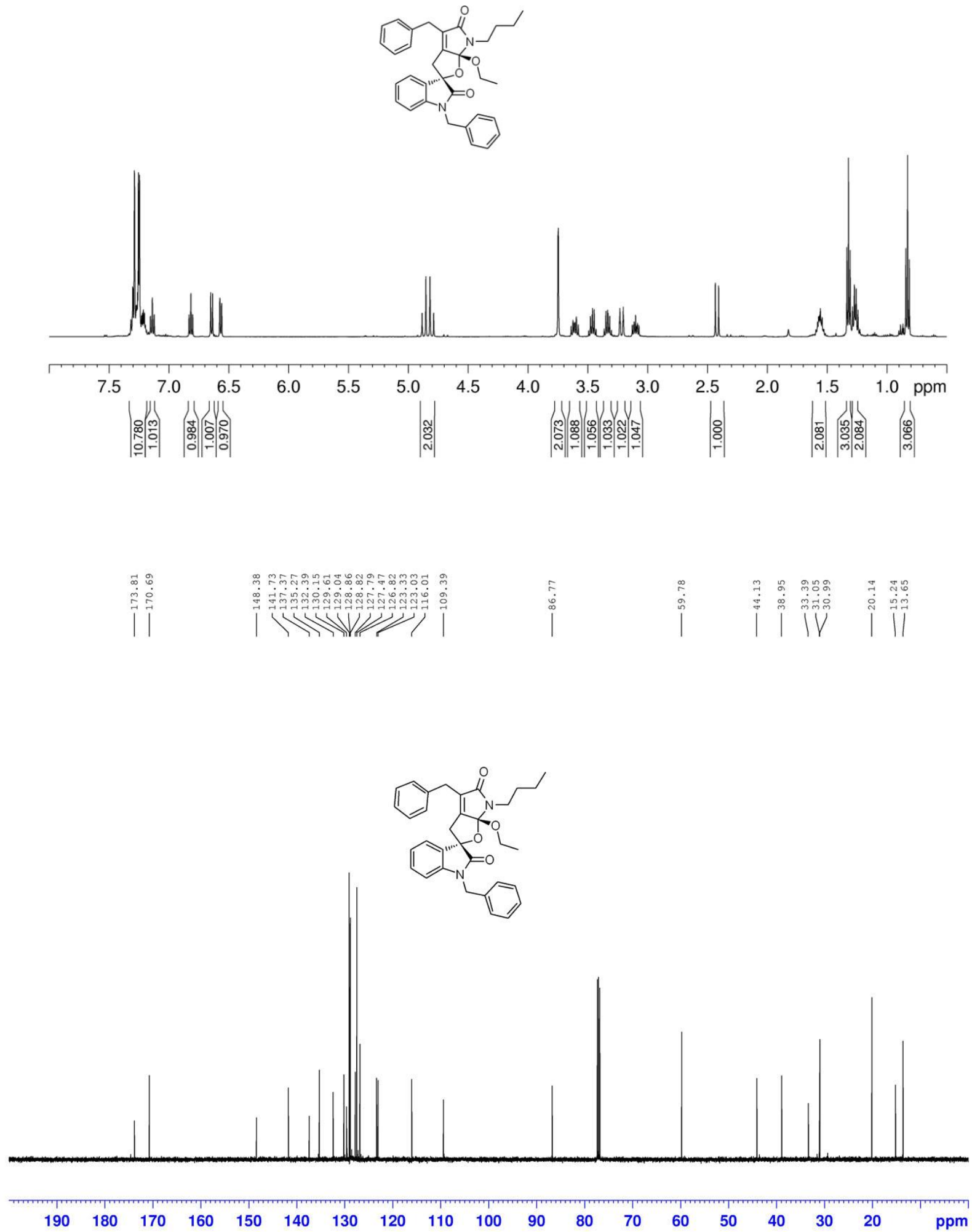


\section{Compound $\mathbf{4 f}$}

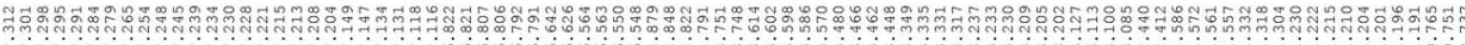

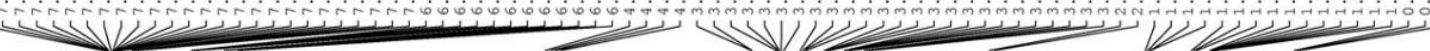

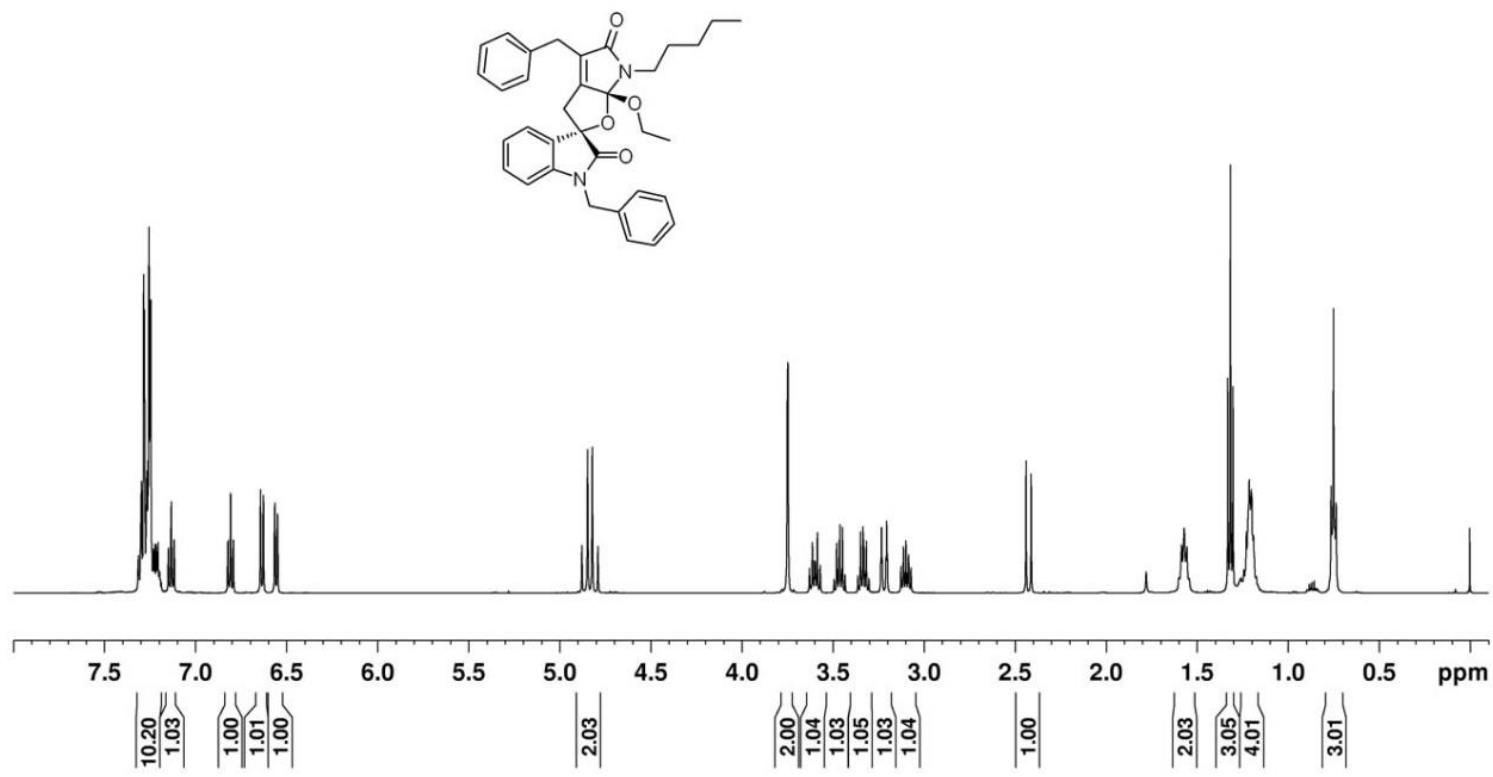

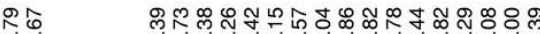

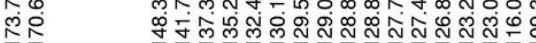

1 (
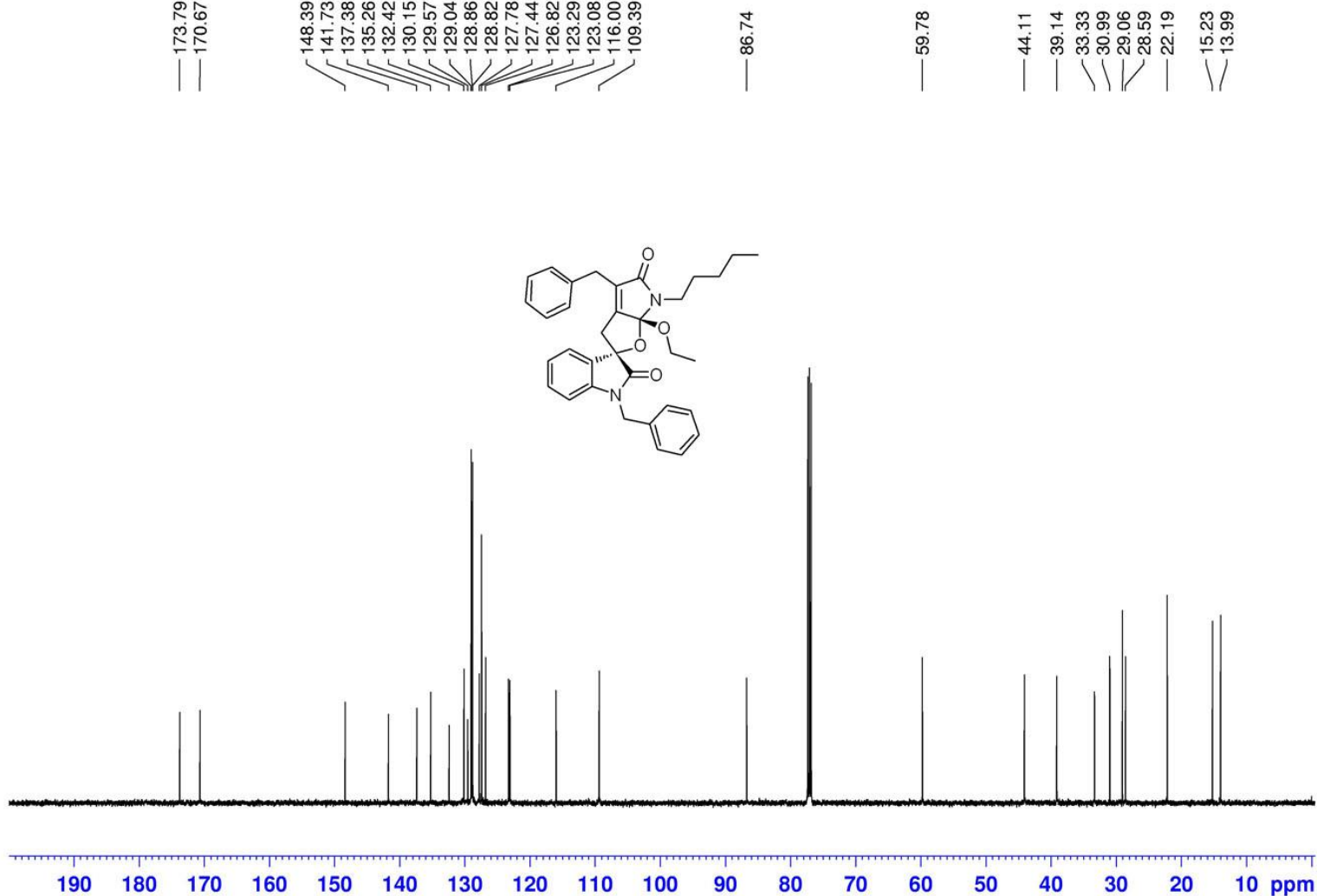


\section{Compound 4g}

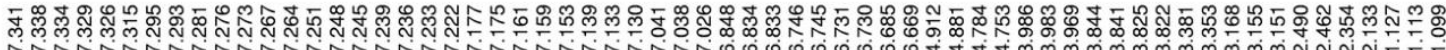

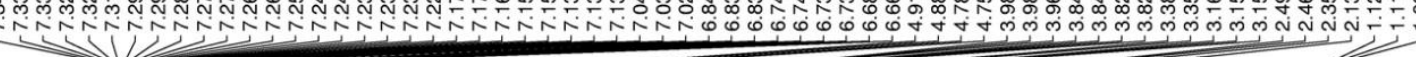

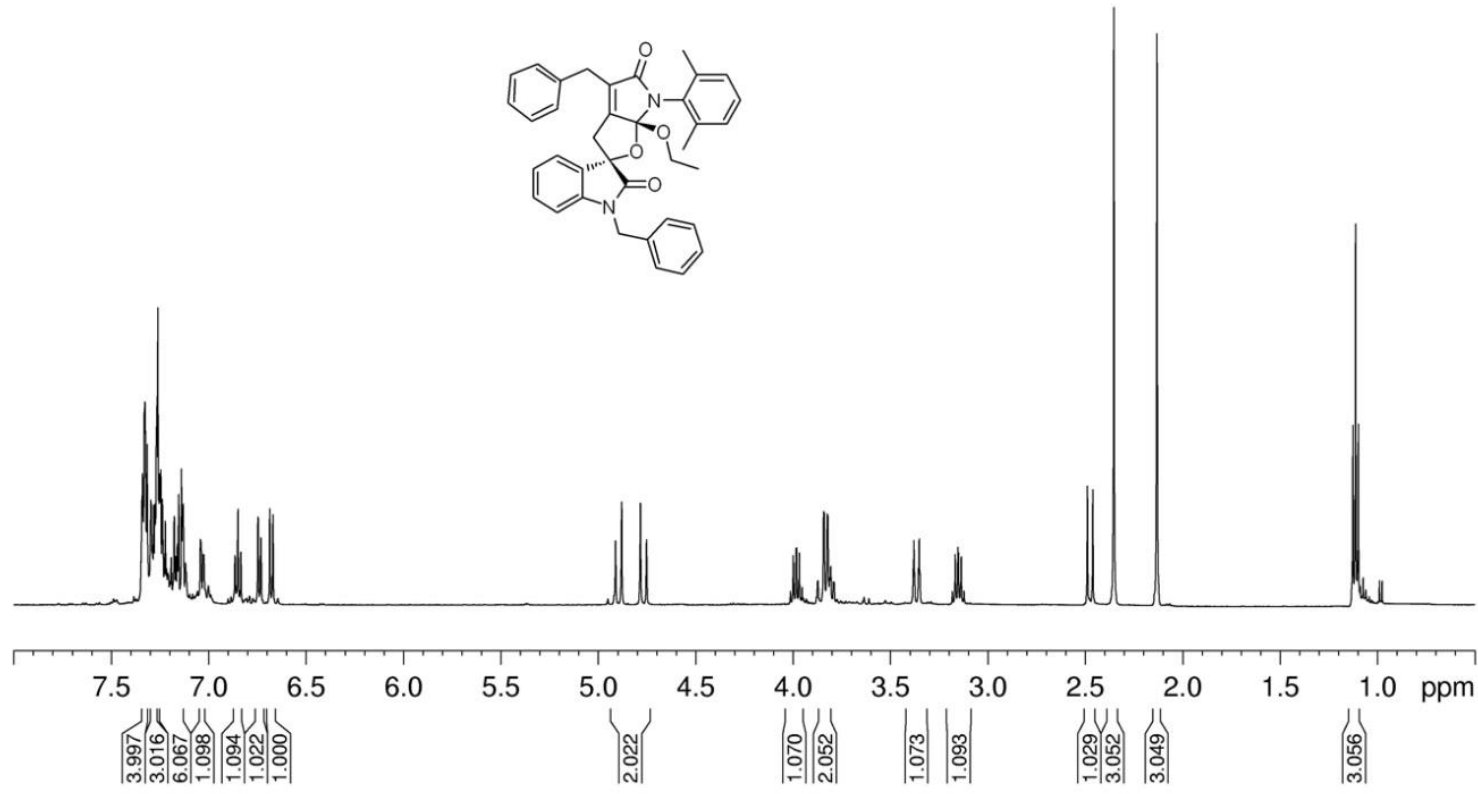

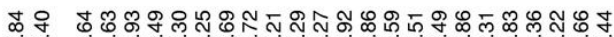

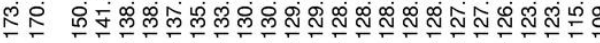

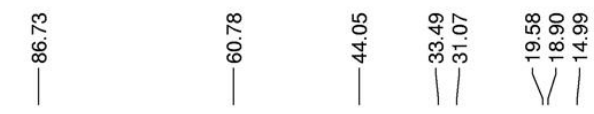
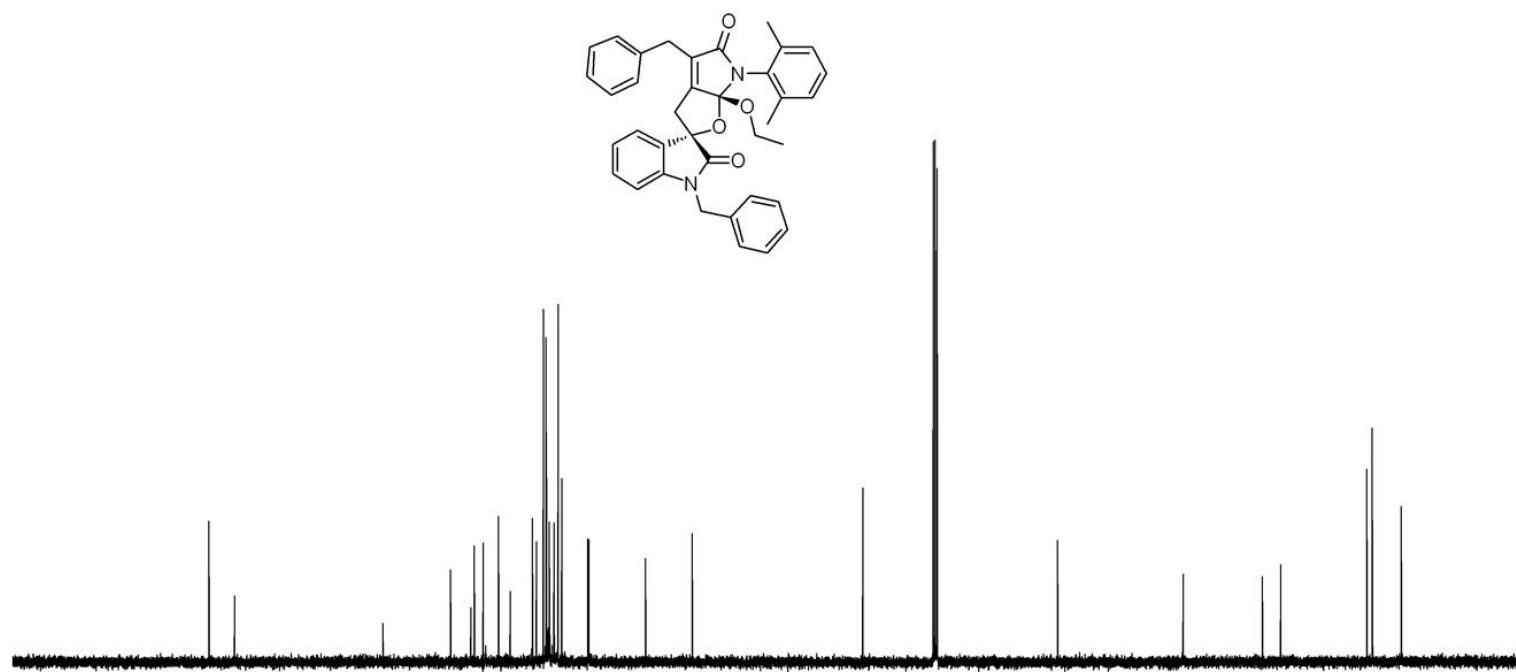

$\begin{array}{lllllllllllllllllll}190 & 180 & 170 & 160 & 150 & 140 & 130 & 120 & 110 & 100 & 90 & 80 & 70 & 60 & 50 & 40 & 30 & 20 & 10 \mathrm{ppm}\end{array}$ 


\section{Compound $\mathbf{4 h}$}
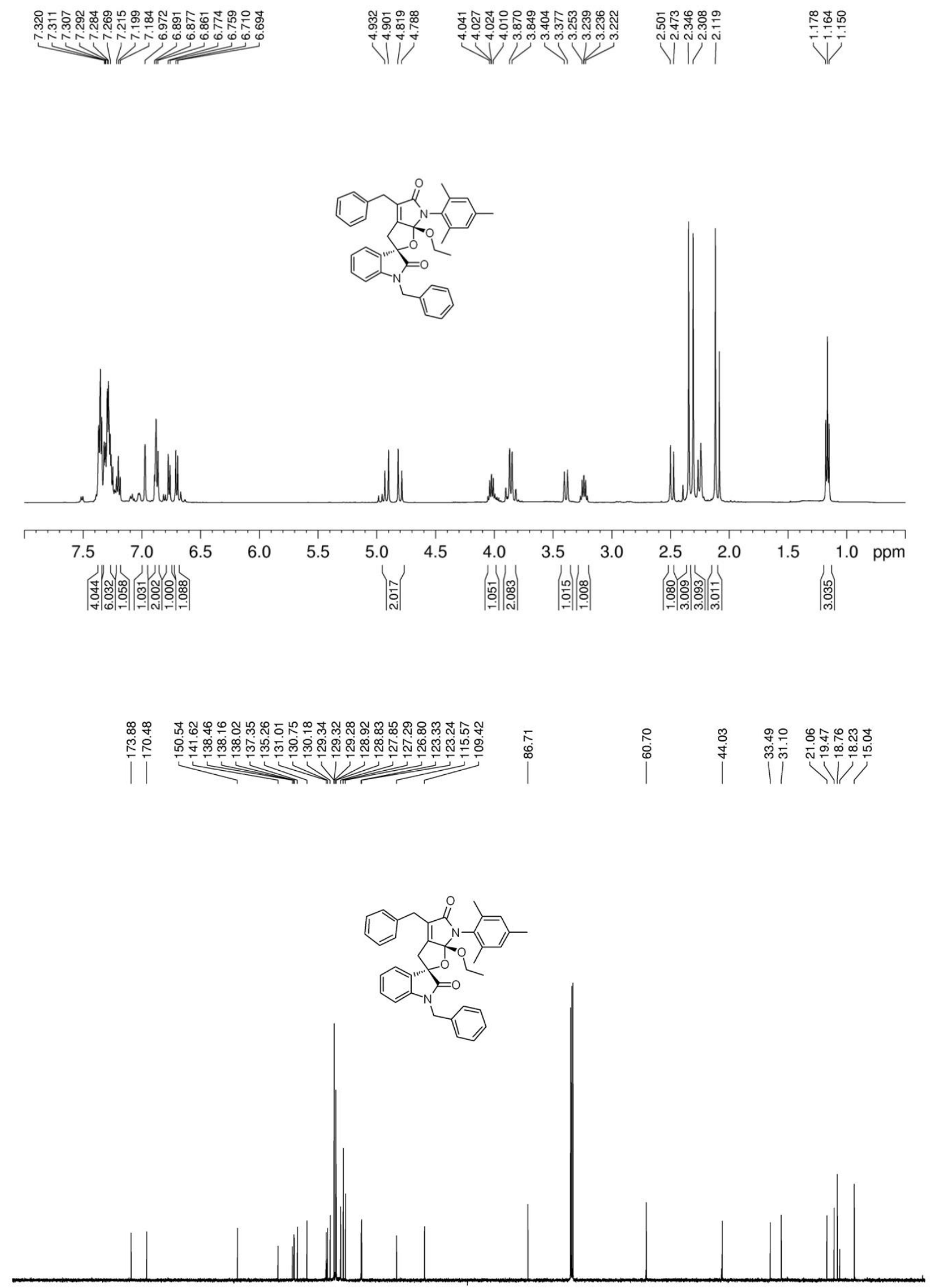

$\begin{array}{lllllllllllllllllll}190 & 180 & 170 & 160 & 150 & 140 & 130 & 120 & 110 & 100 & 90 & 80 & 70 & 60 & 50 & 40 & 30 & 20 & 10\end{array}$ 


\section{Compound 5a}

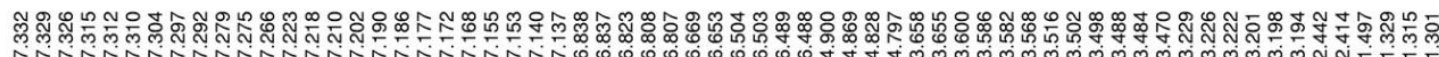

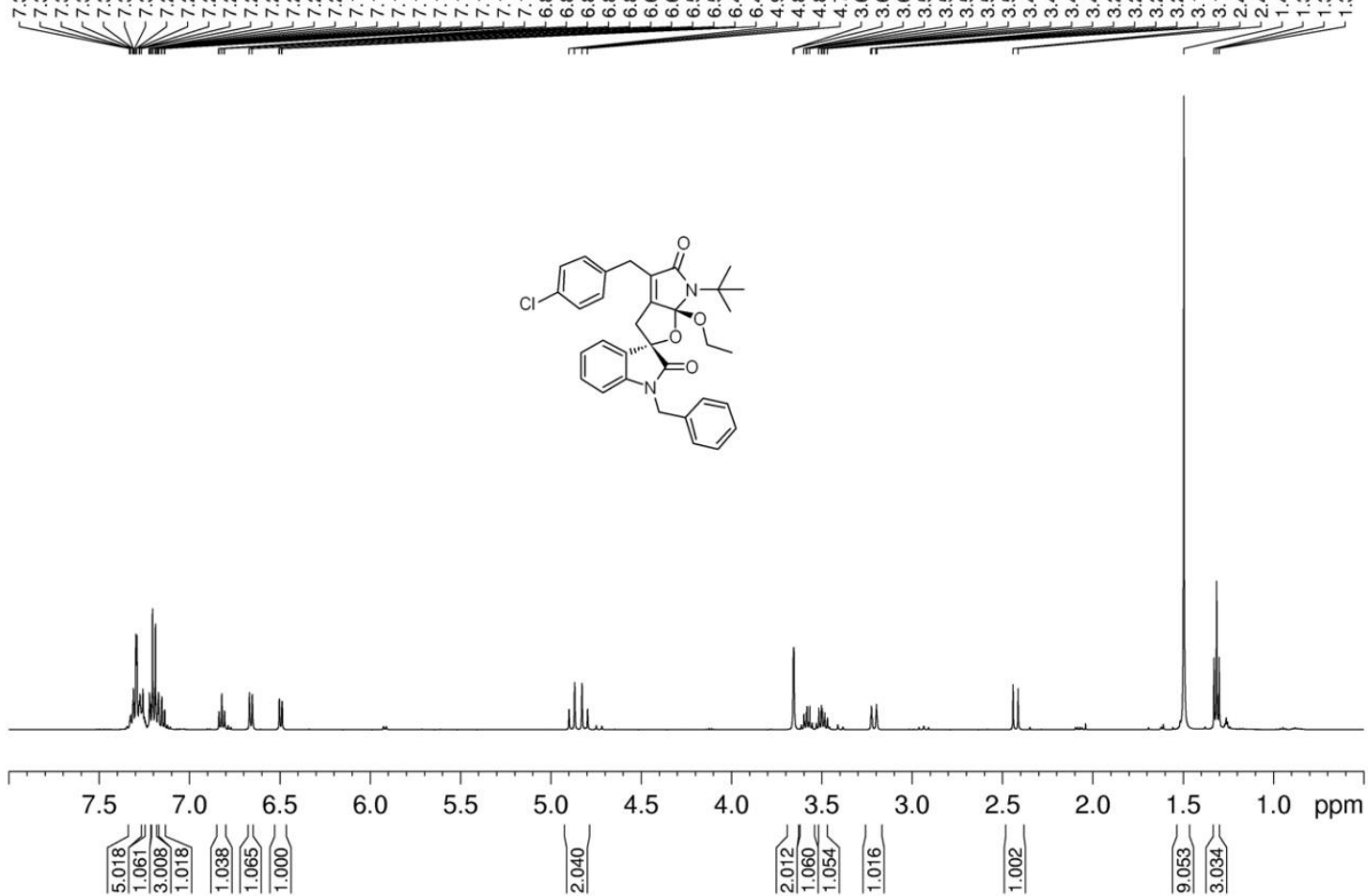

$\underbrace{\mid}$
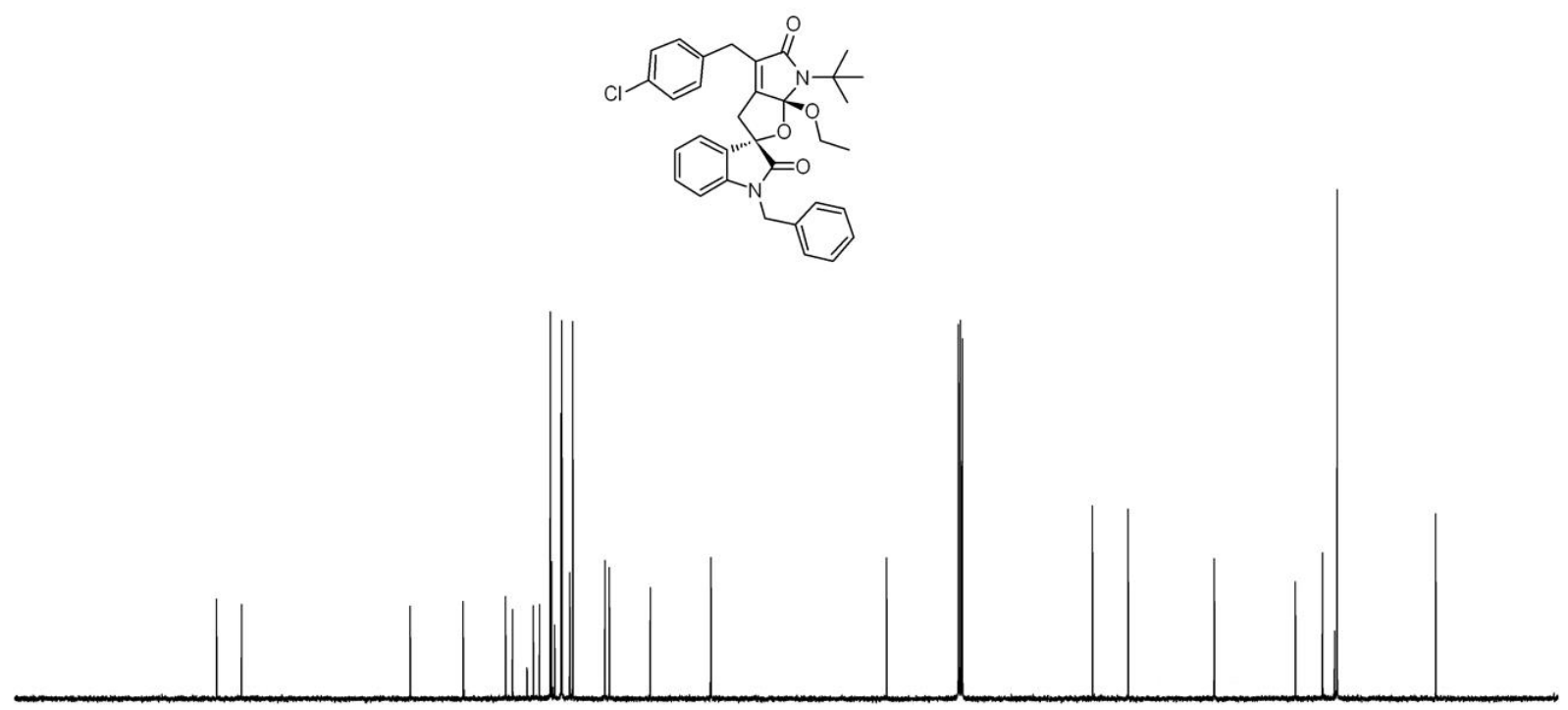

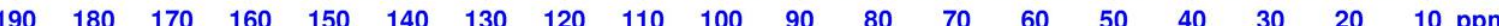




\section{Compound 5b}

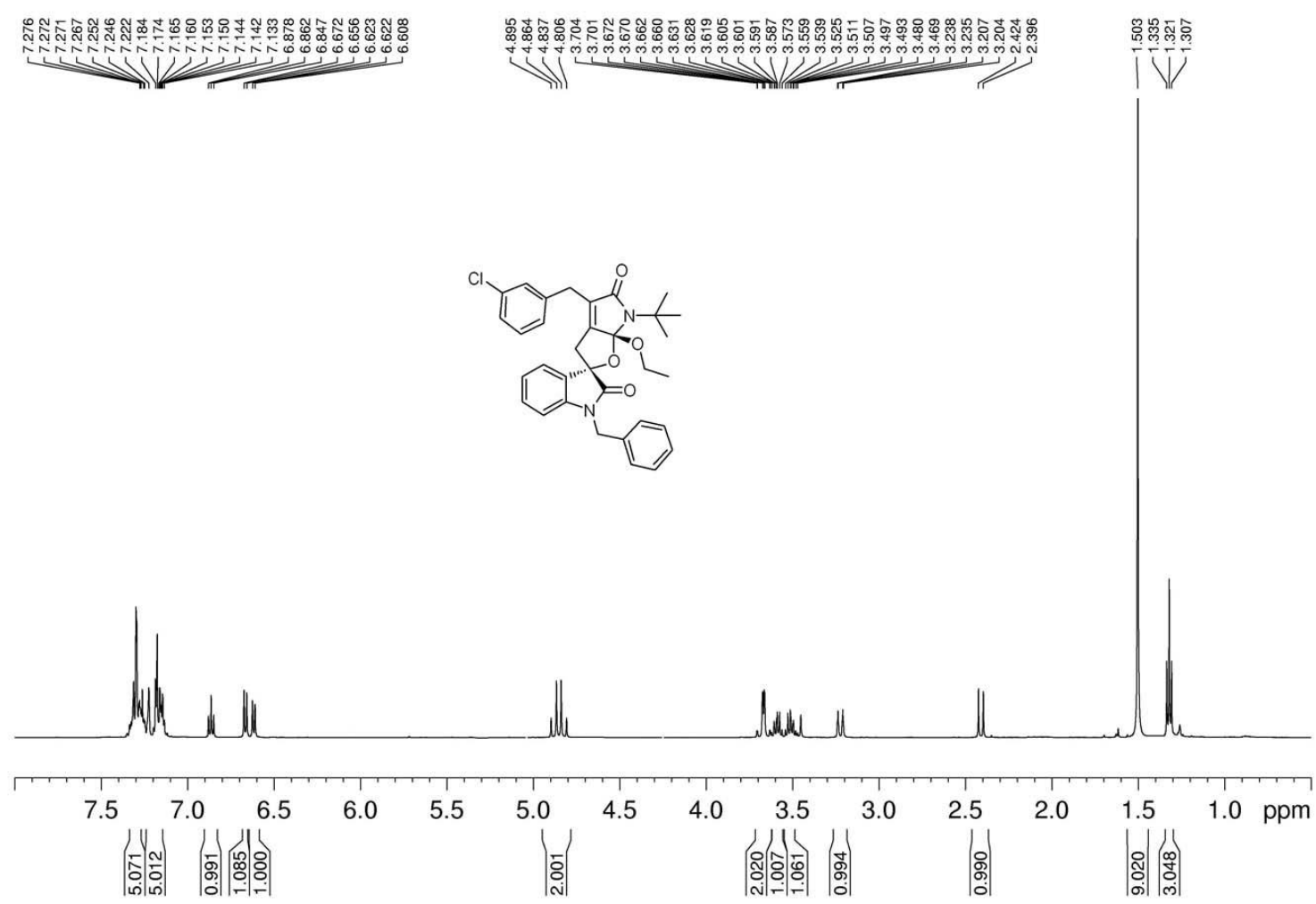

|

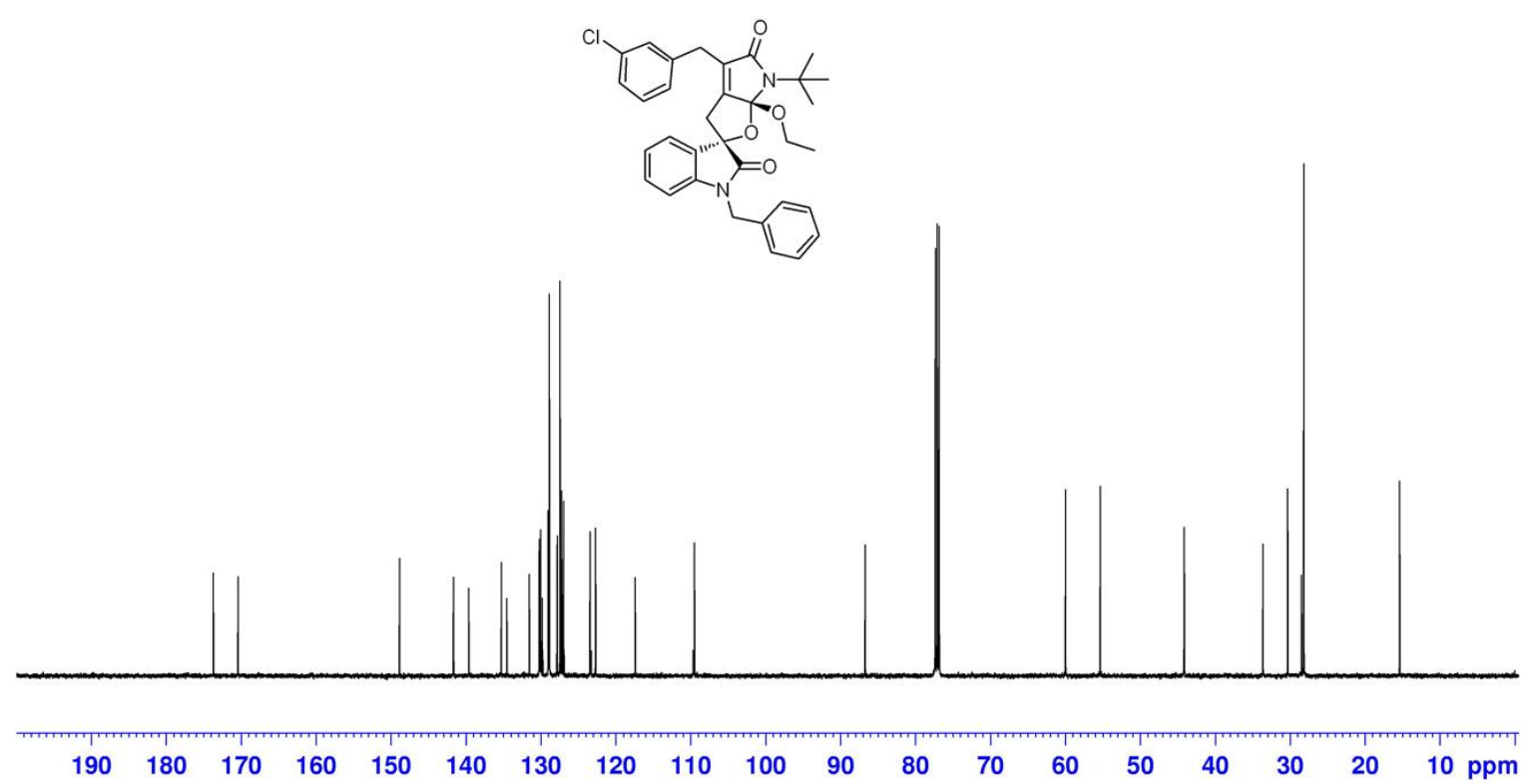




\section{Compound 5c}

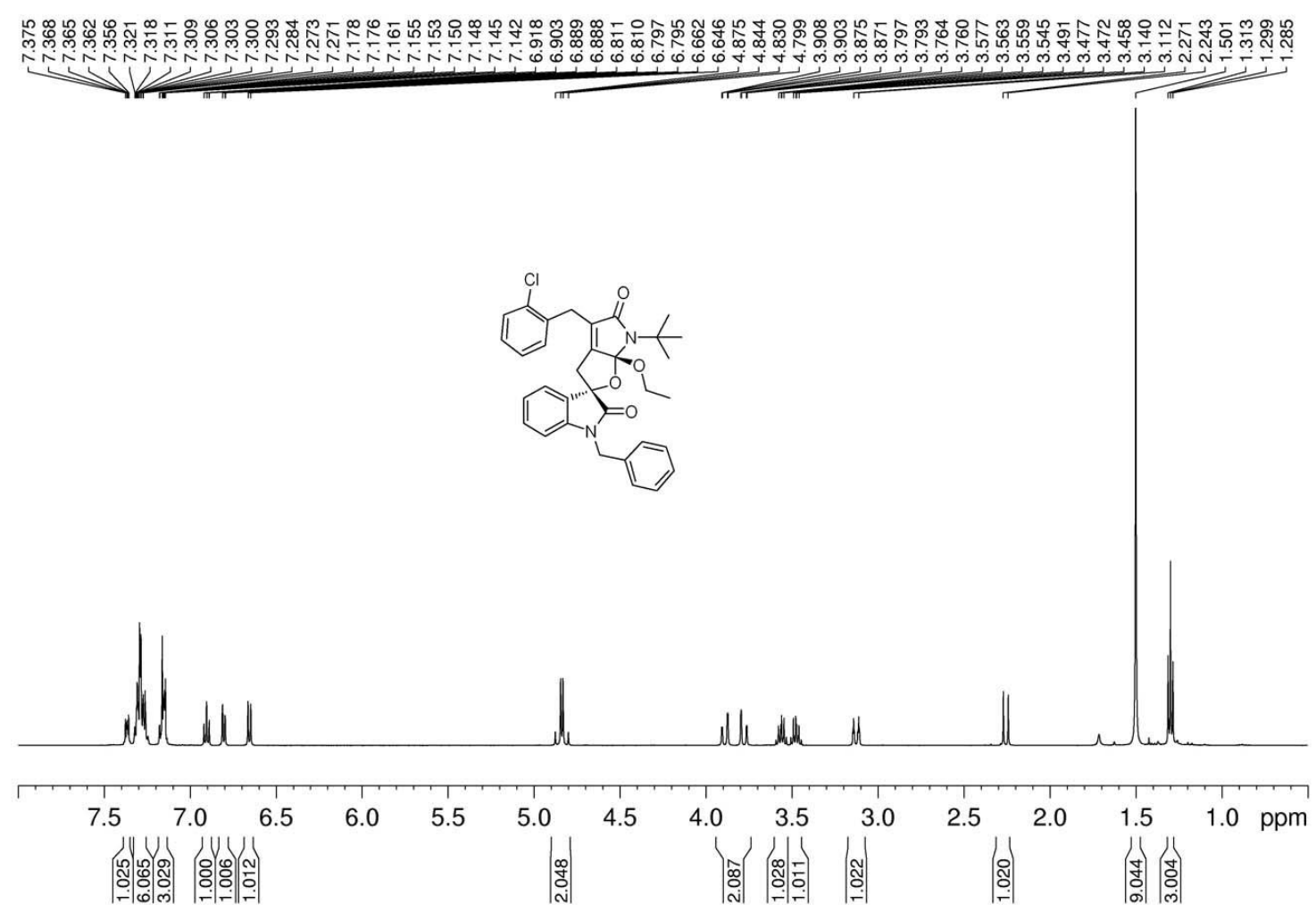

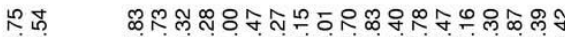

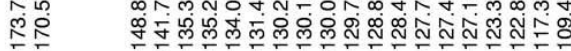

$1 \mid$

$\mid$
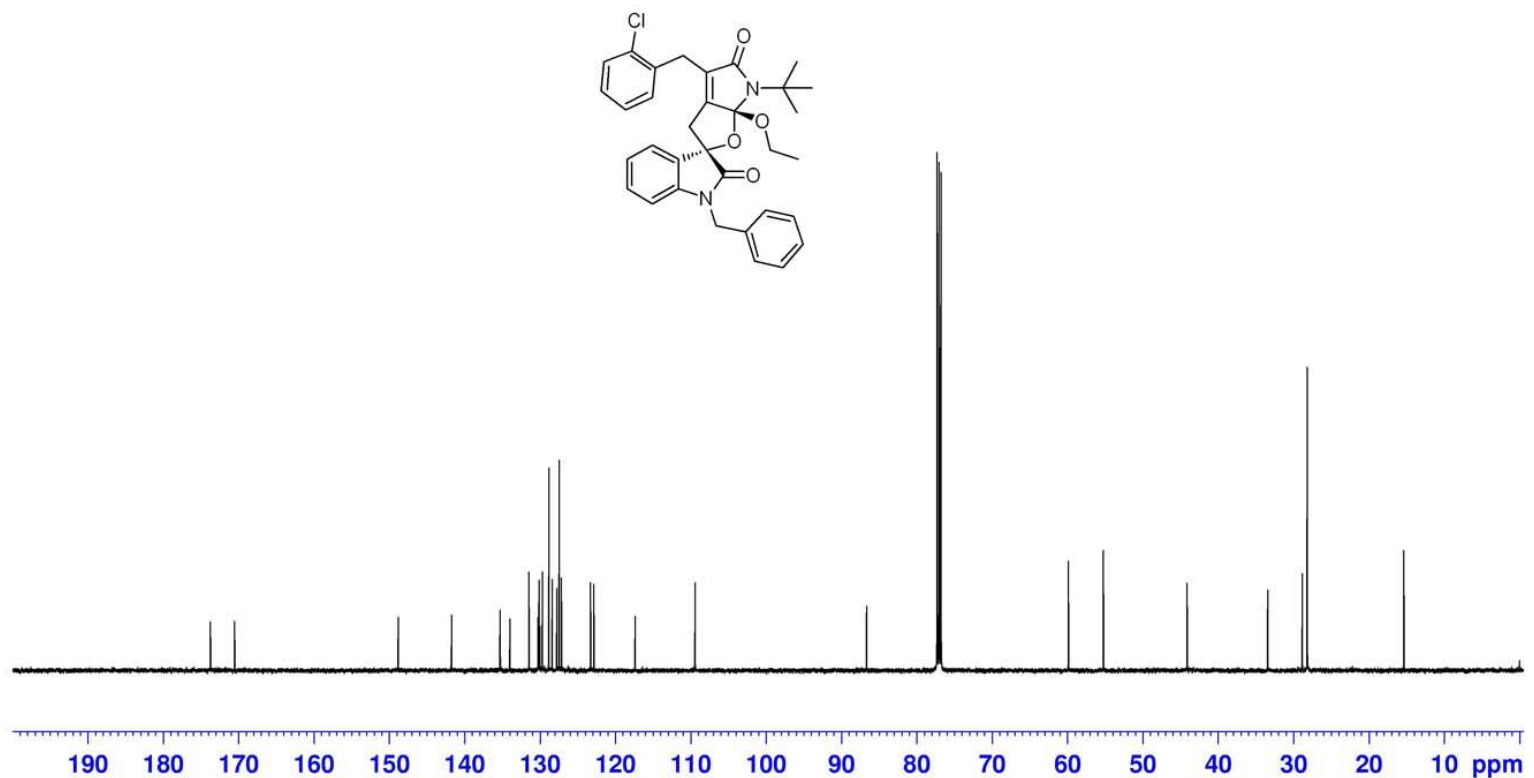


\section{Compound 5d}

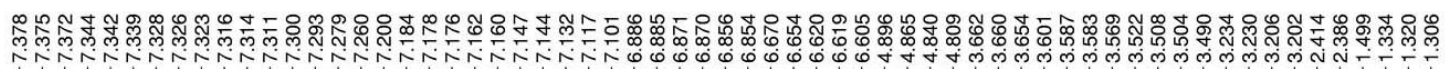

选 N

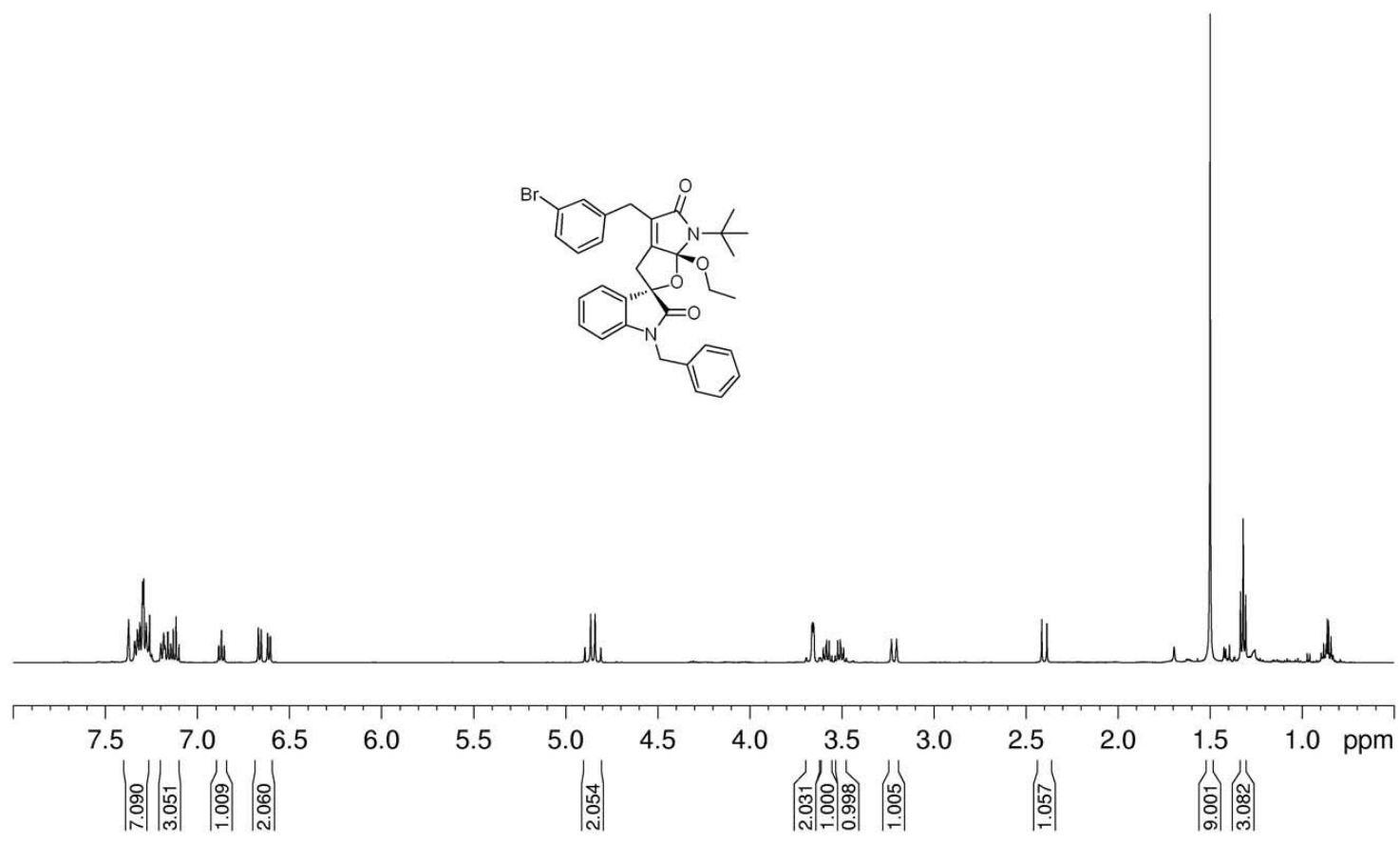

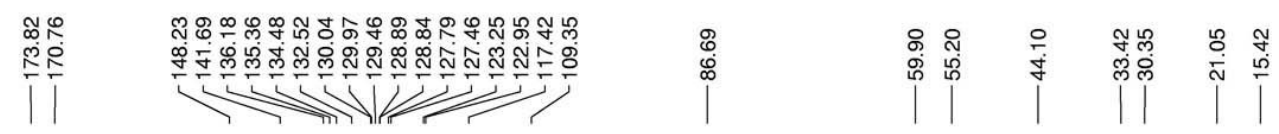

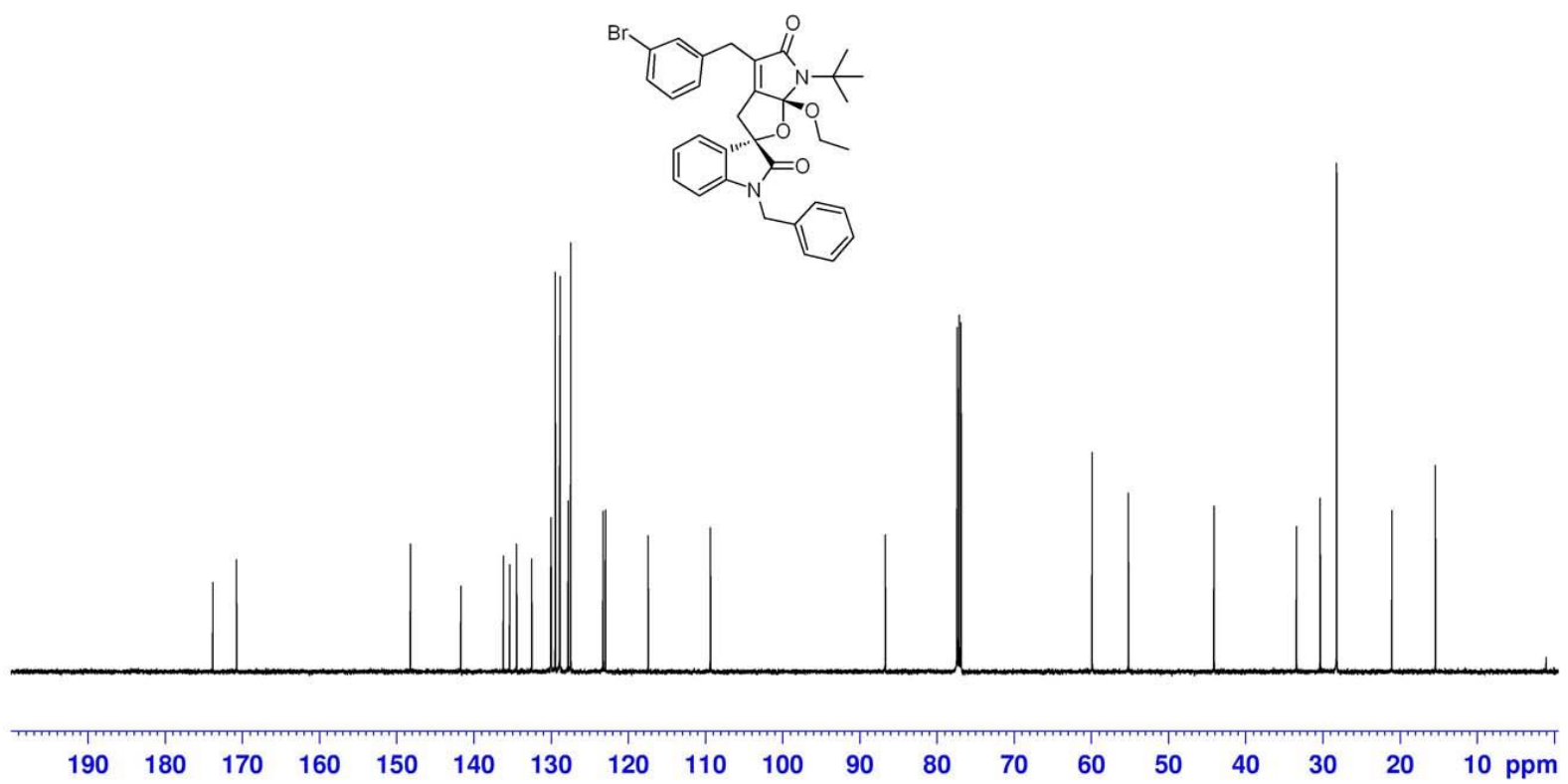




\section{Compound 5e}

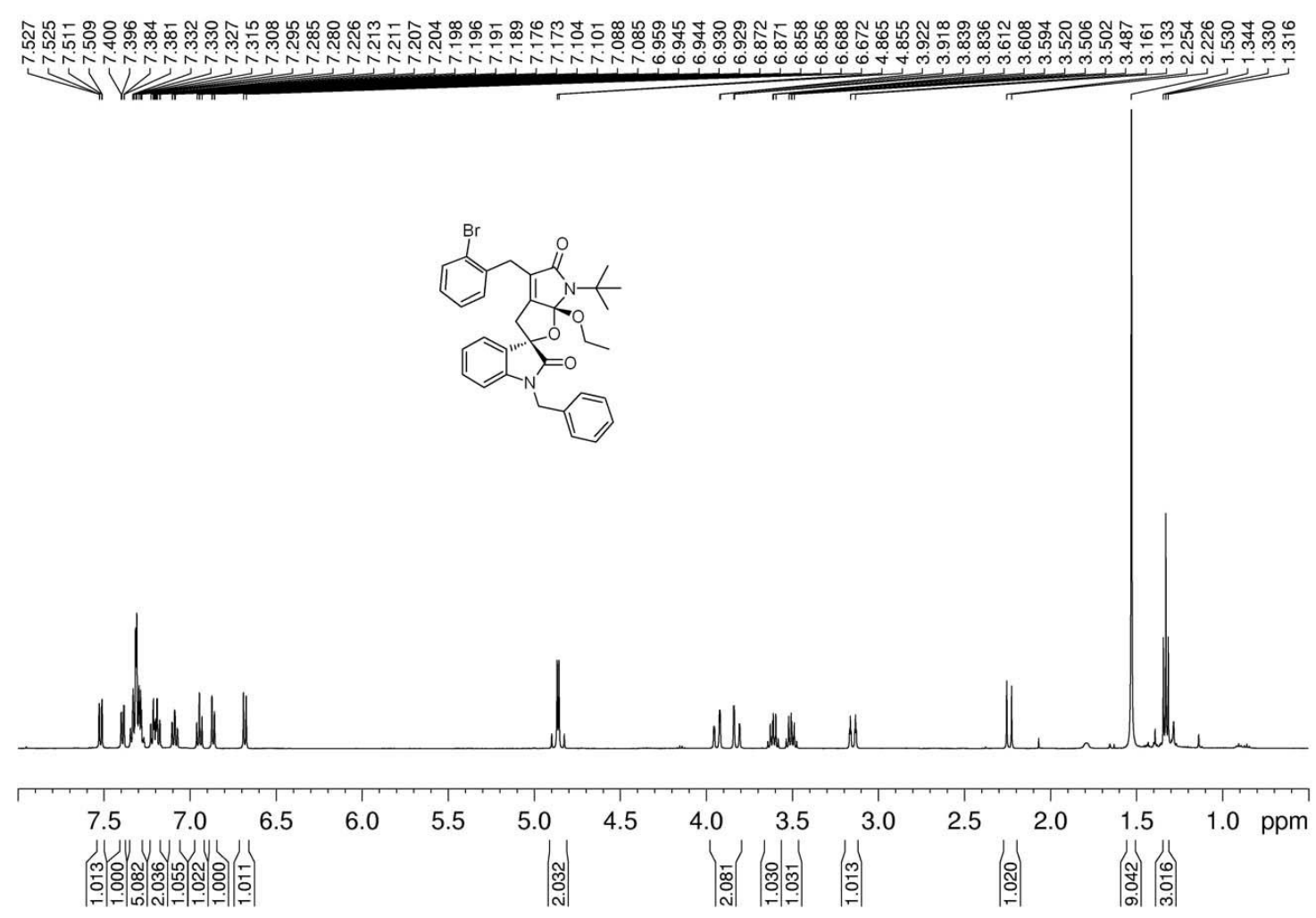

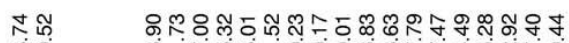

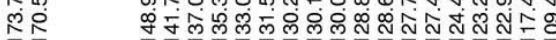

II

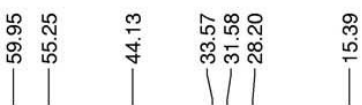

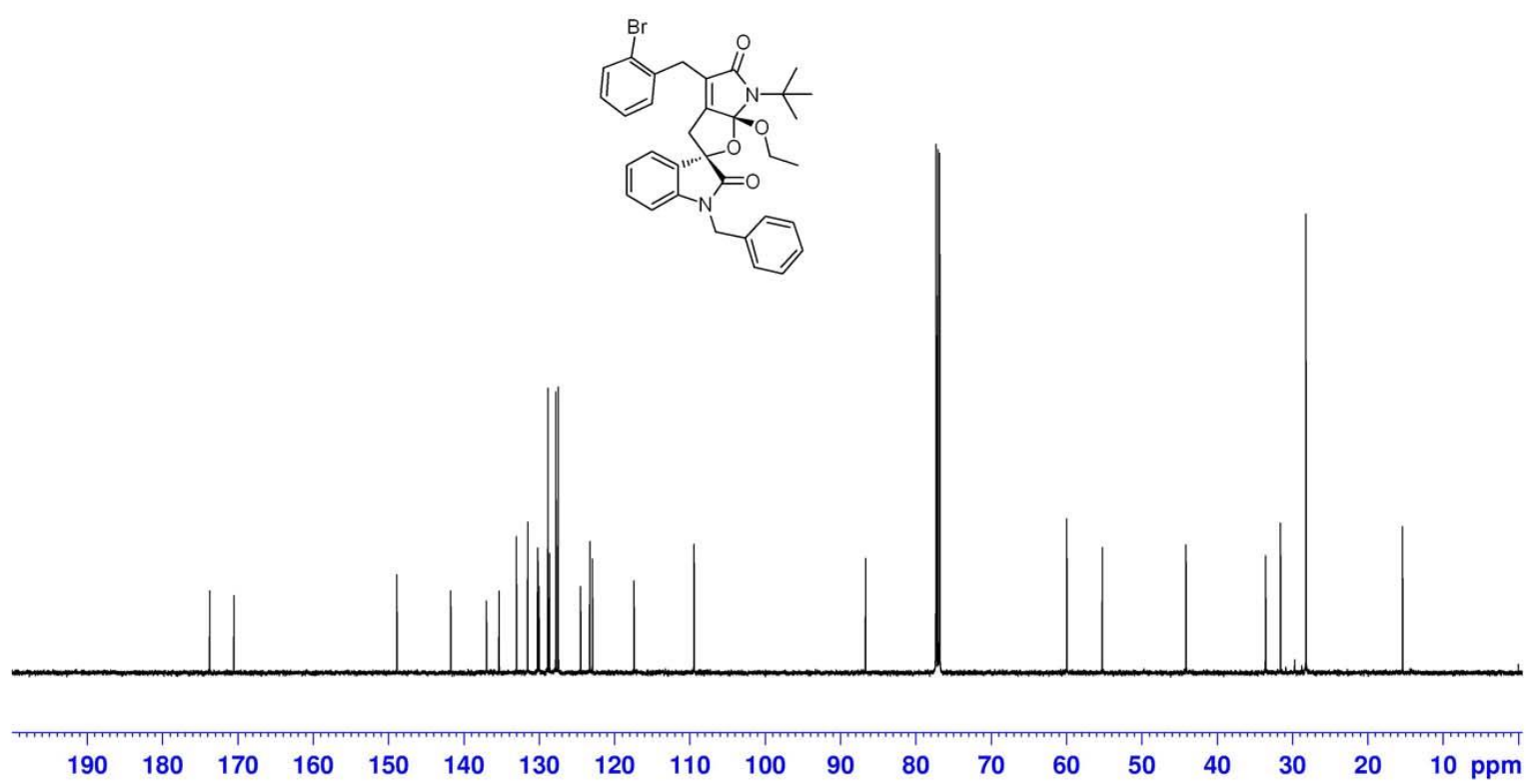




\section{Compound $\mathbf{5 f}$}

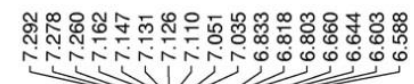

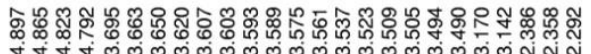

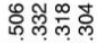

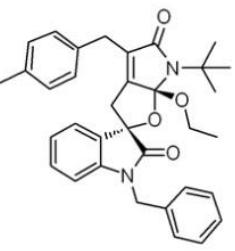

Mulu

Whe

Ul

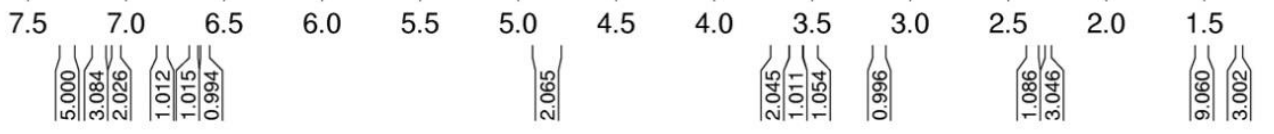

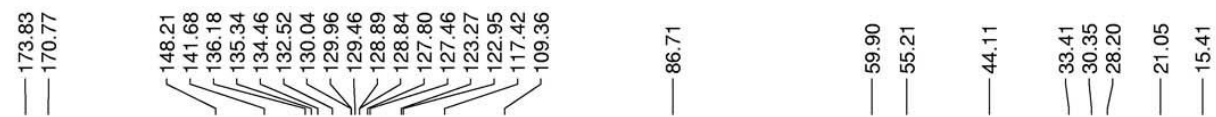
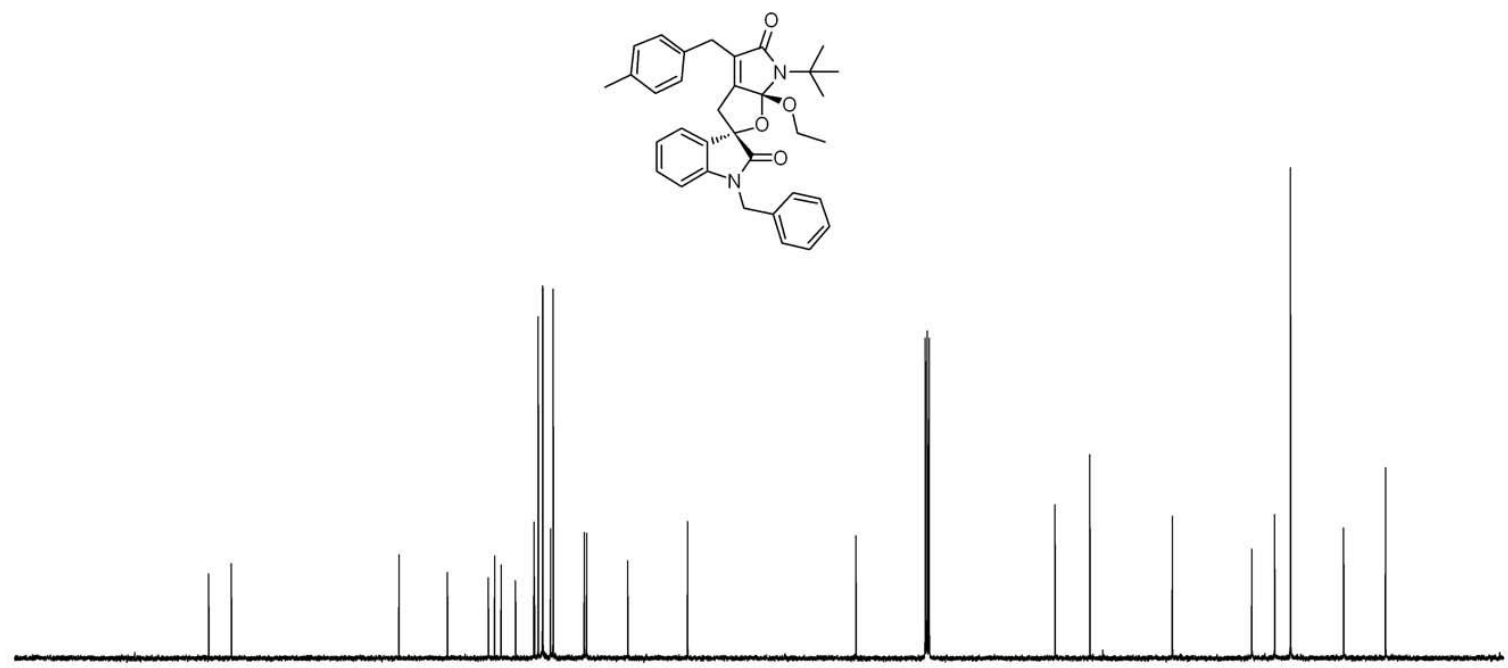

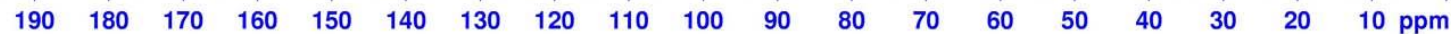




\section{Compound 5g}

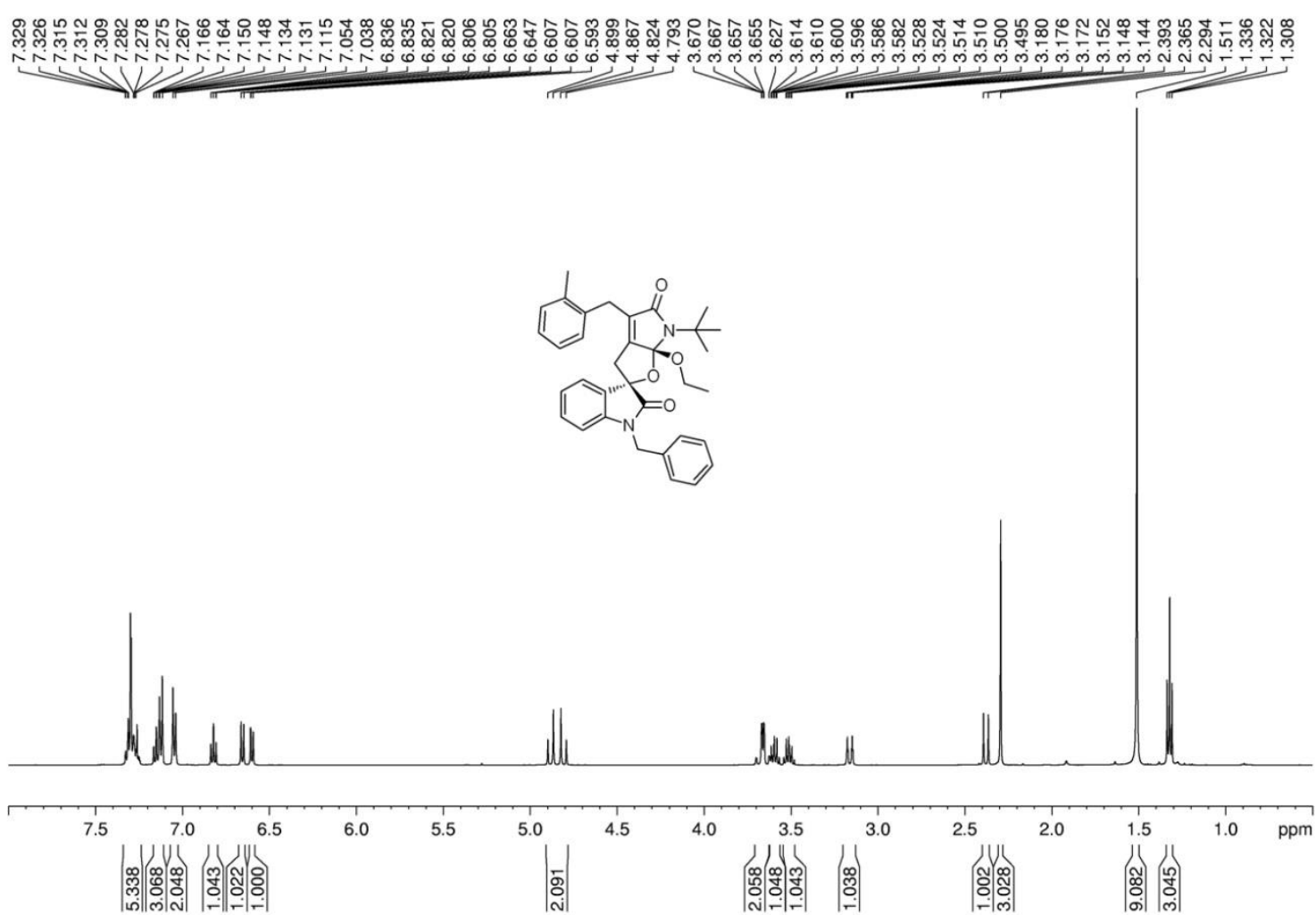

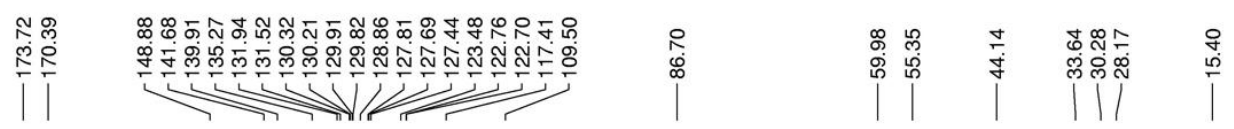

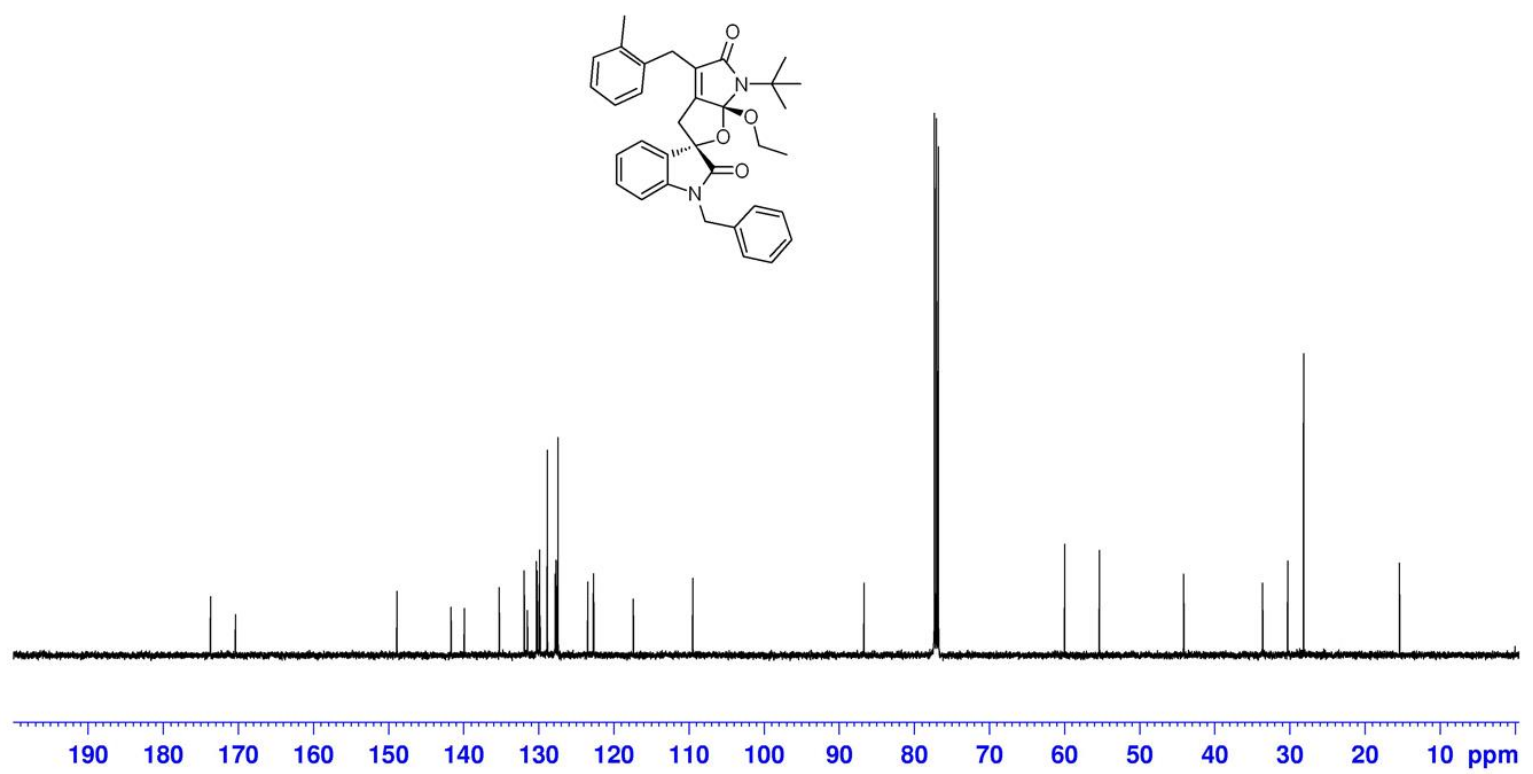




\section{Compound $\mathbf{6 a}$}
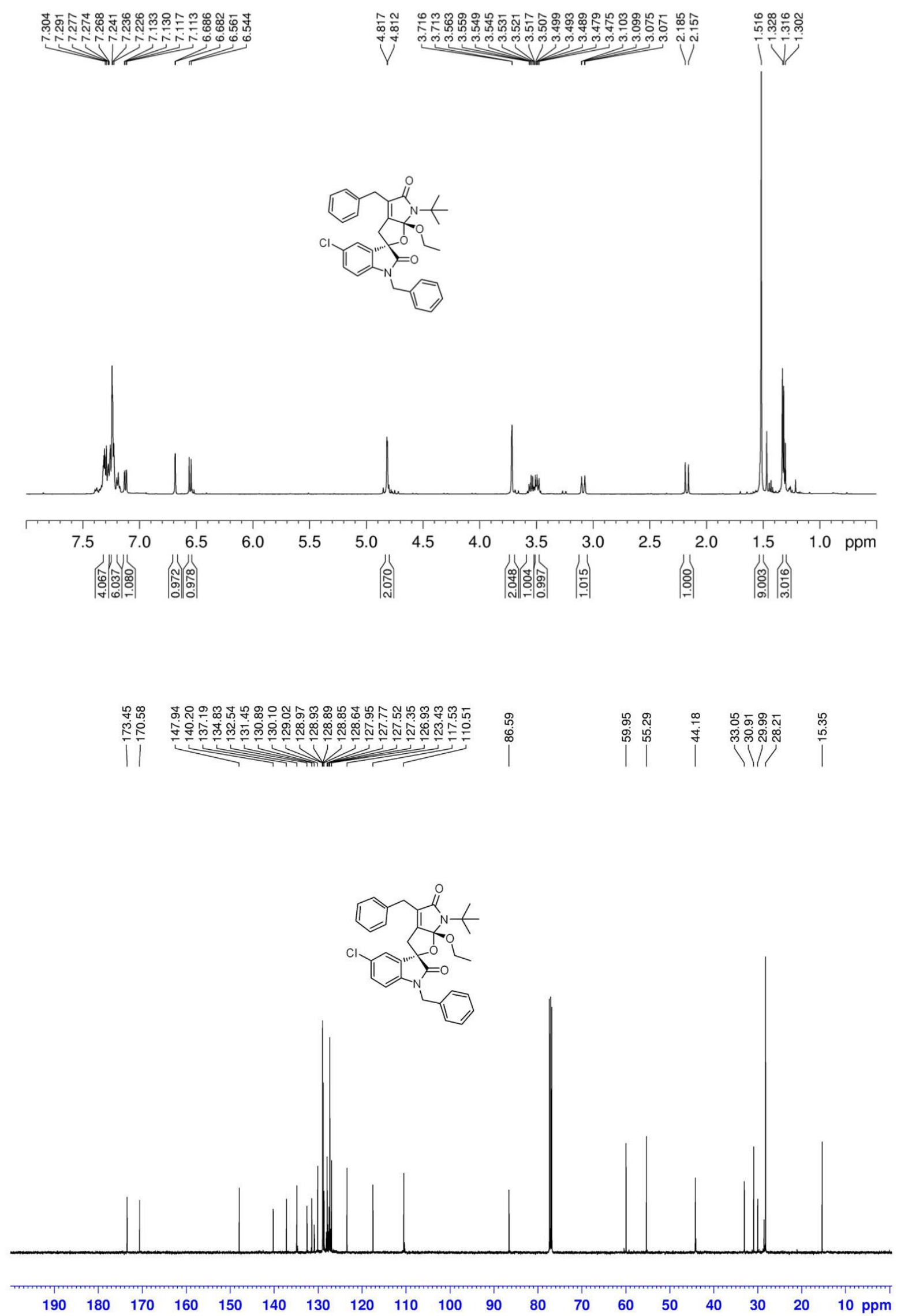


\section{Compound $\mathbf{6 b}$}

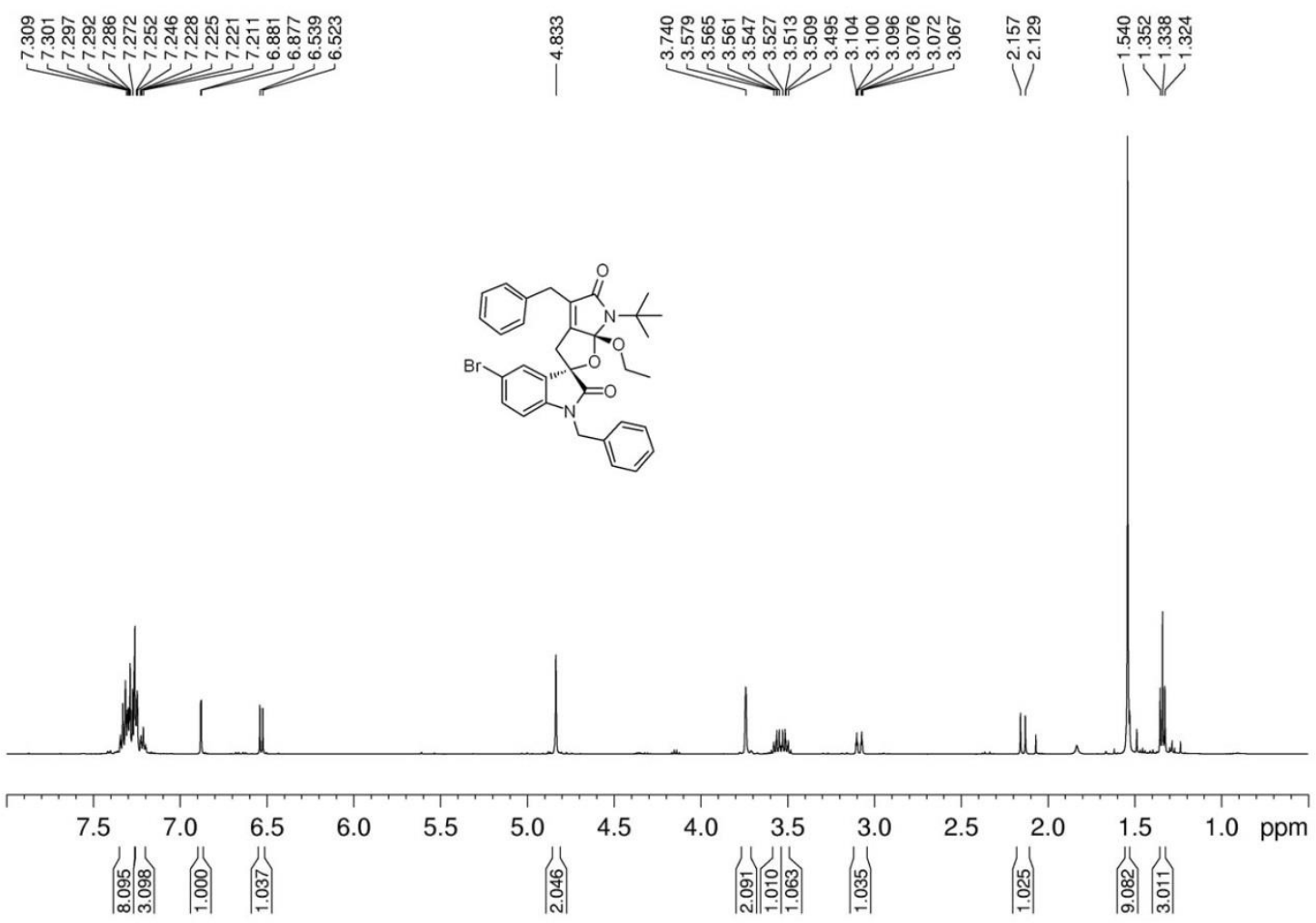

||

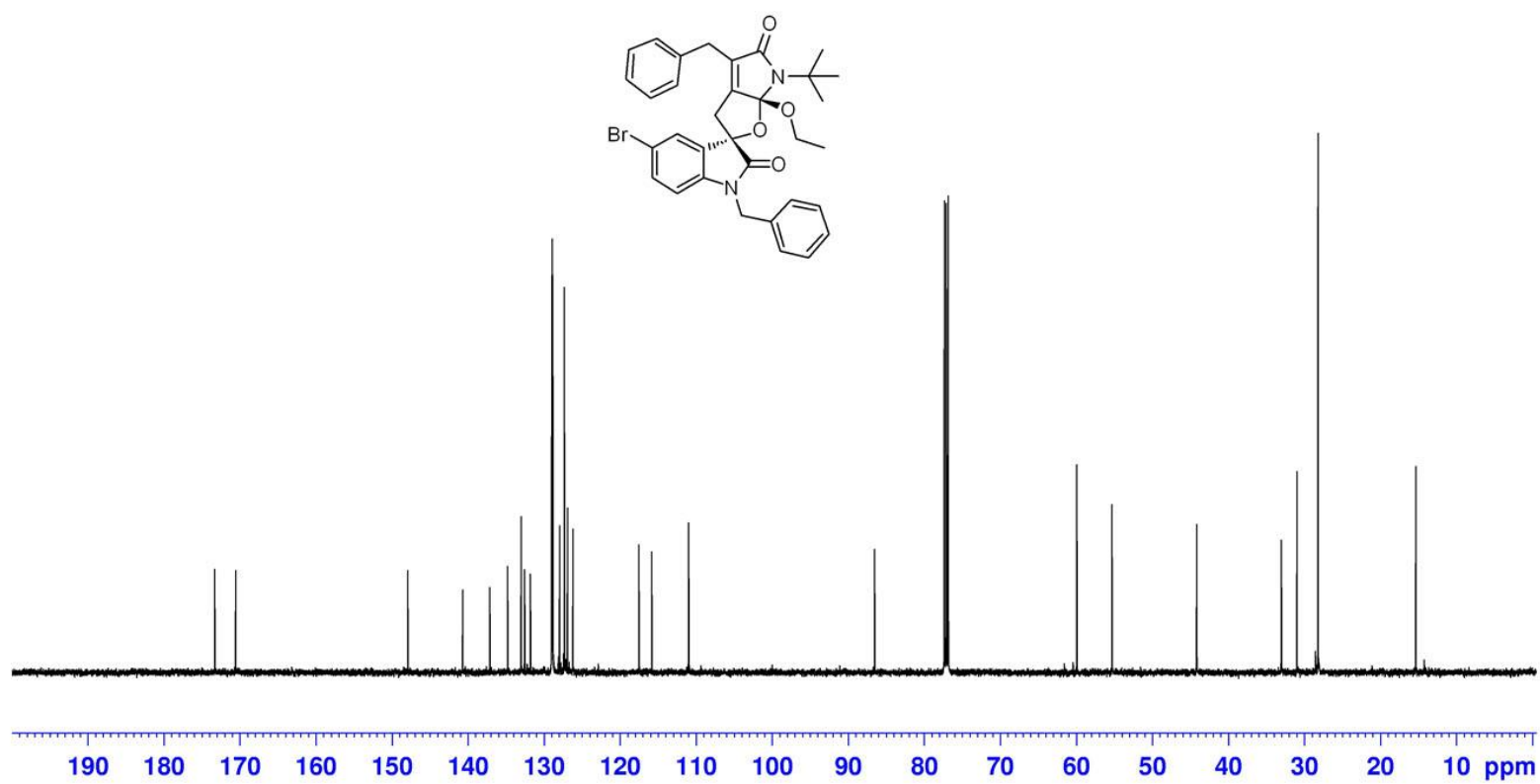




\section{Compound 6c}

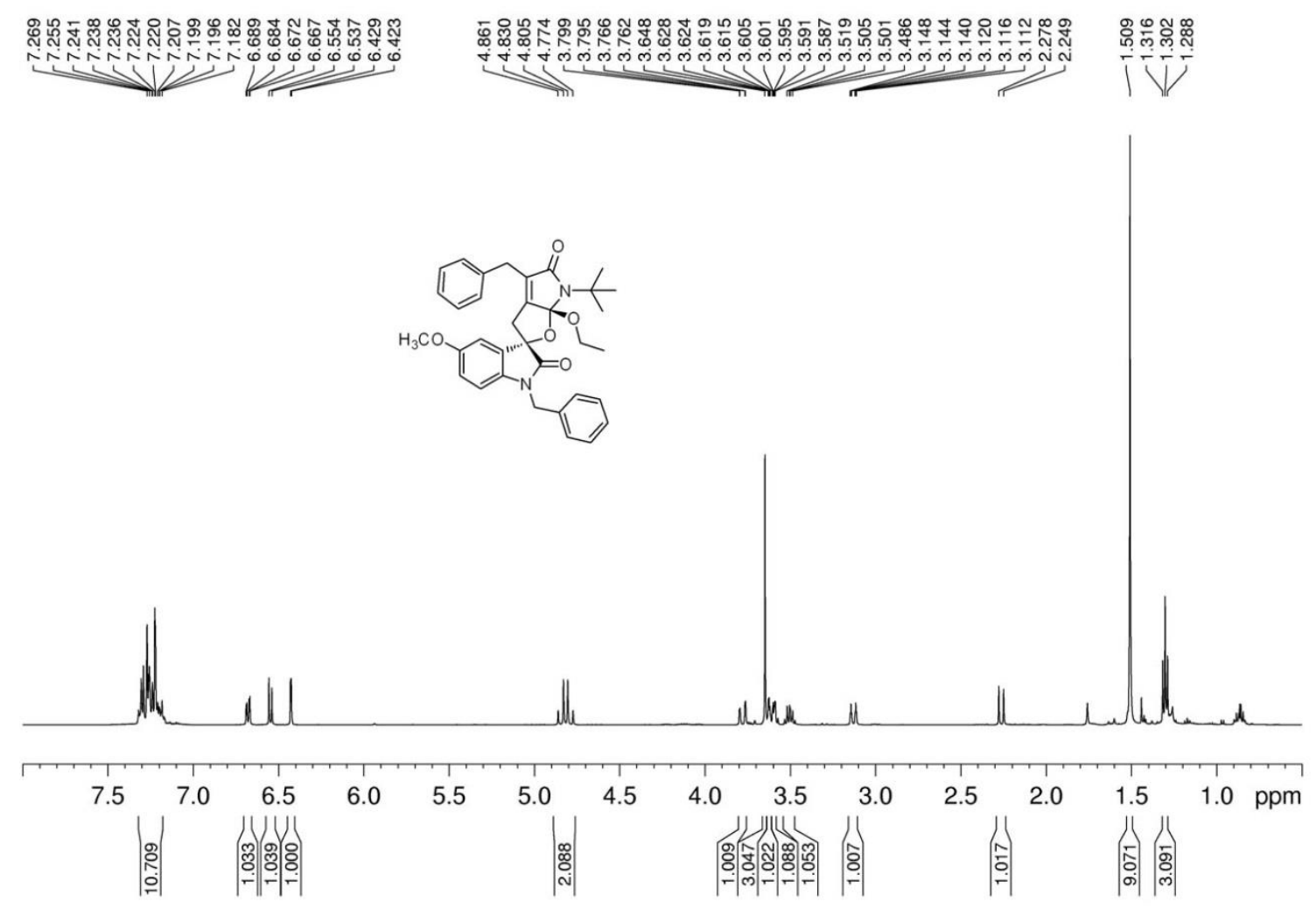

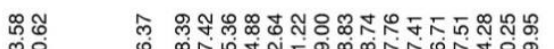

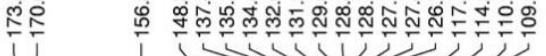

II

|

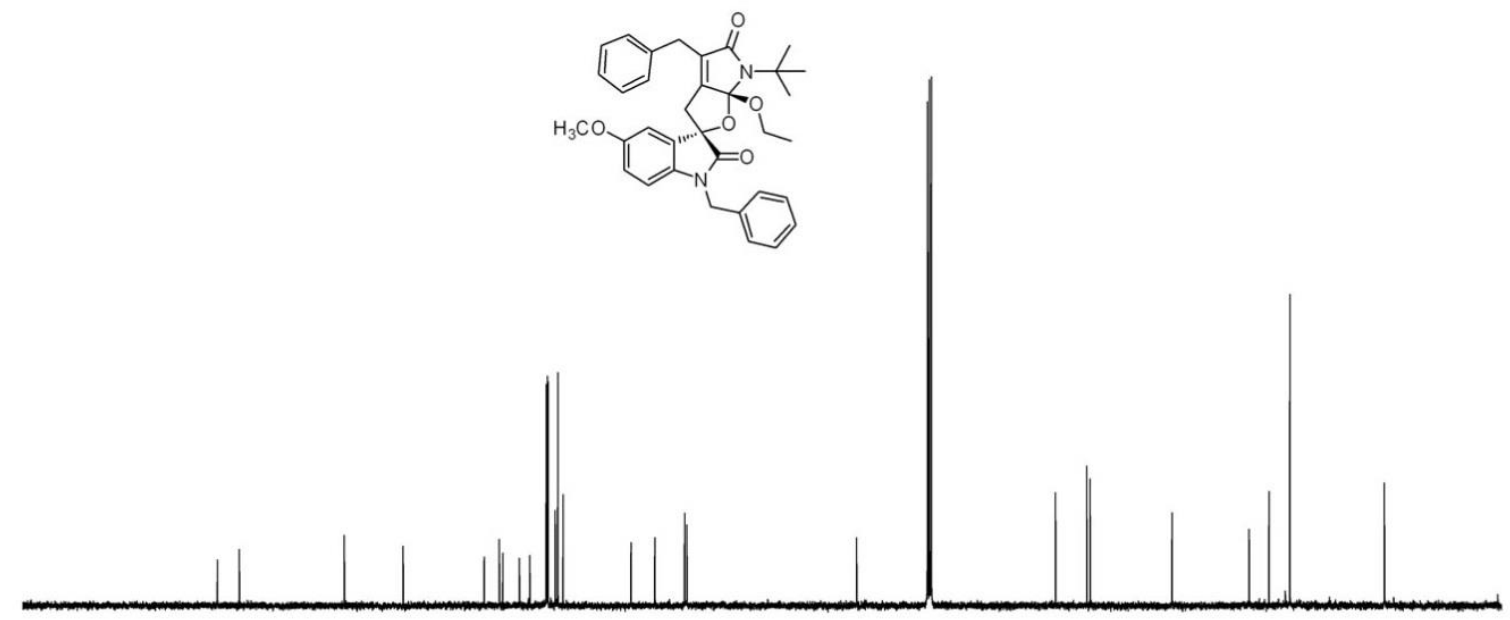

$\begin{array}{llllllllllllllllllll}190 & 180 & 170 & 160 & 150 & 140 & 130 & 120 & 110 & 100 & 90 & 80 & 70 & 60 & 50 & 40 & 30 & 20 & 10 & \mathrm{ppm}\end{array}$ 


\section{Compound 6d}

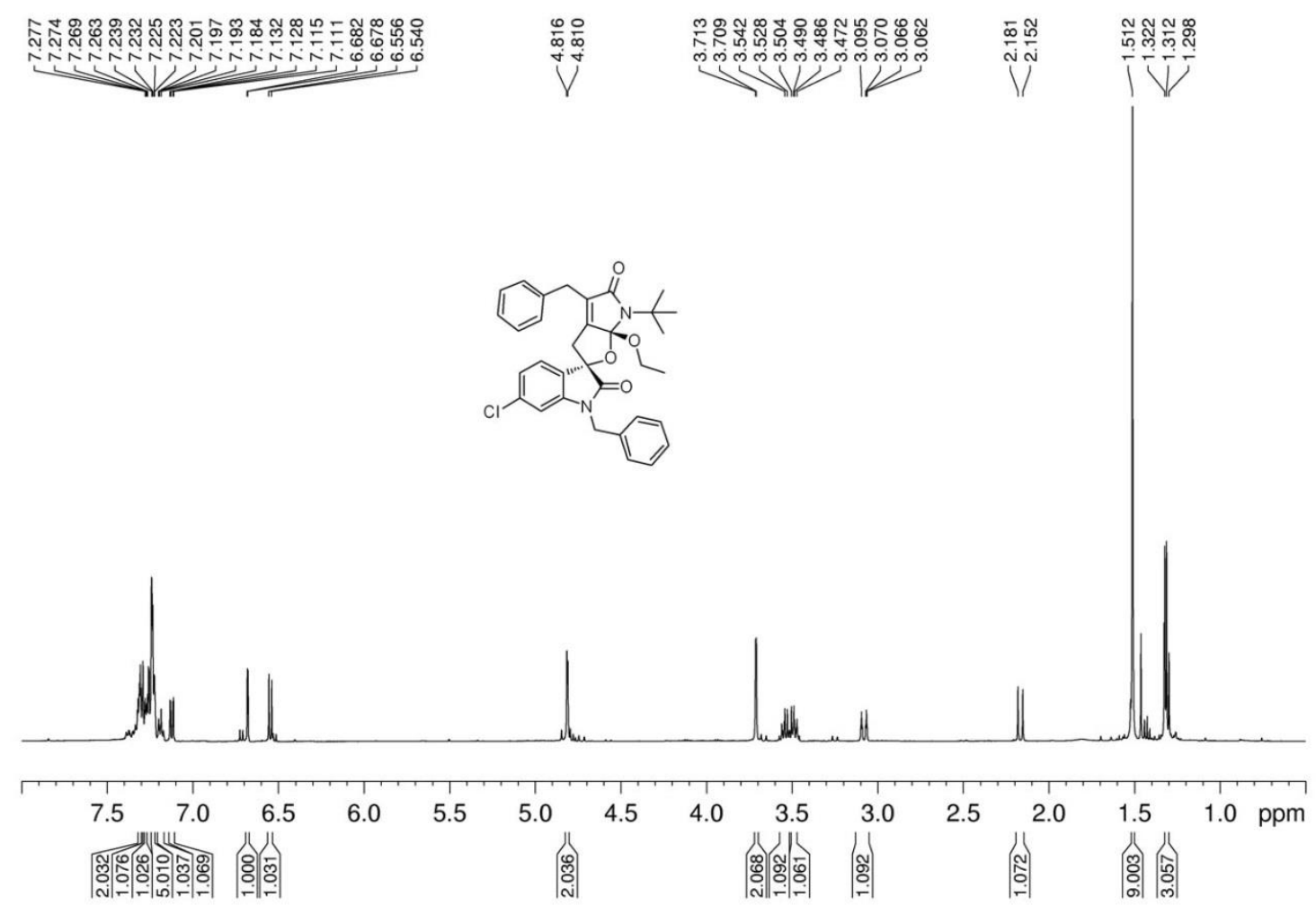

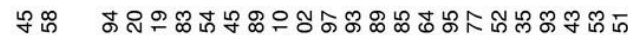

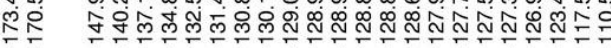

$\left.\right|_{\substack{0 \\ 0 \\ 0}} ^{\infty}$

|

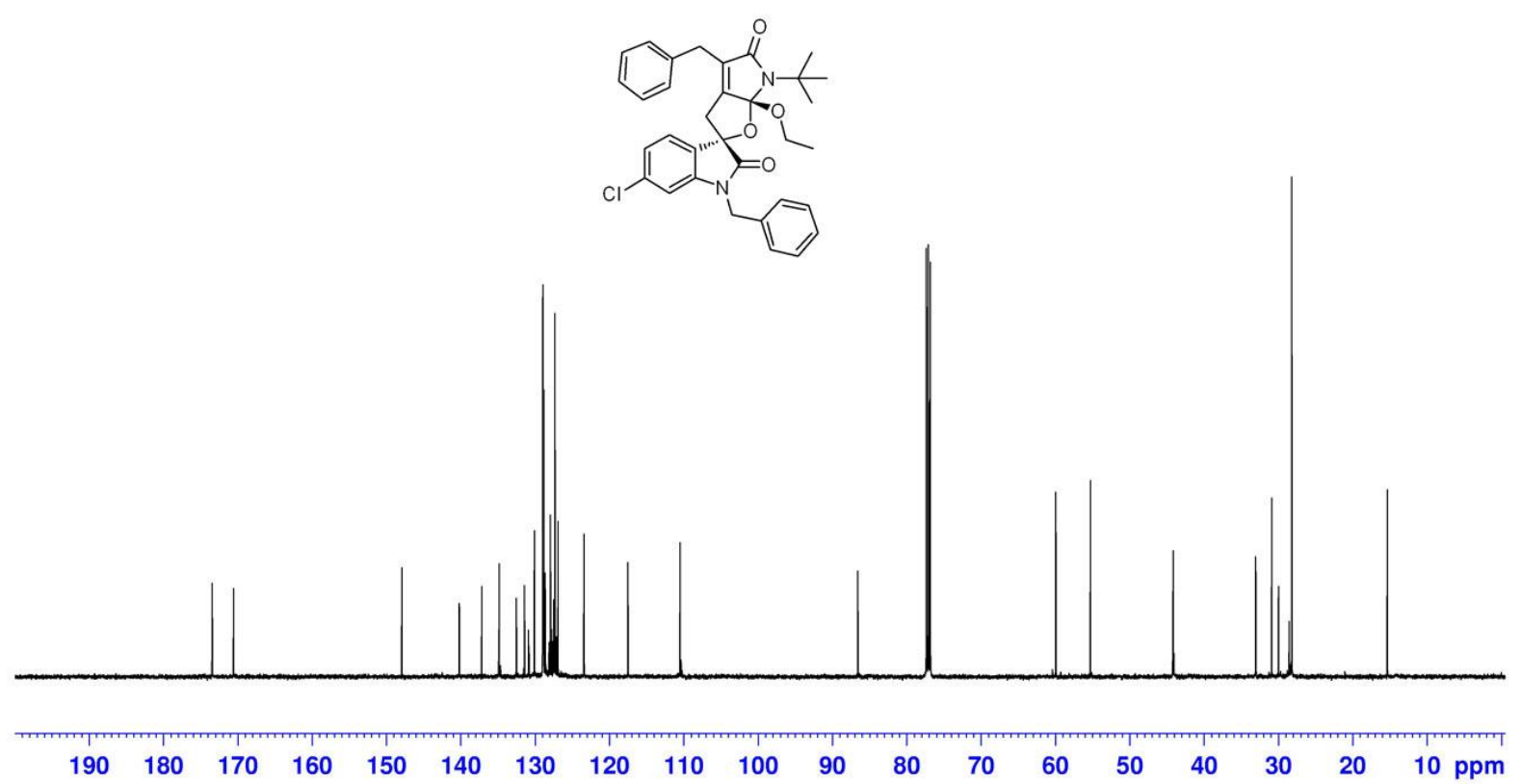




\section{Compound $6 \mathbf{e}$}
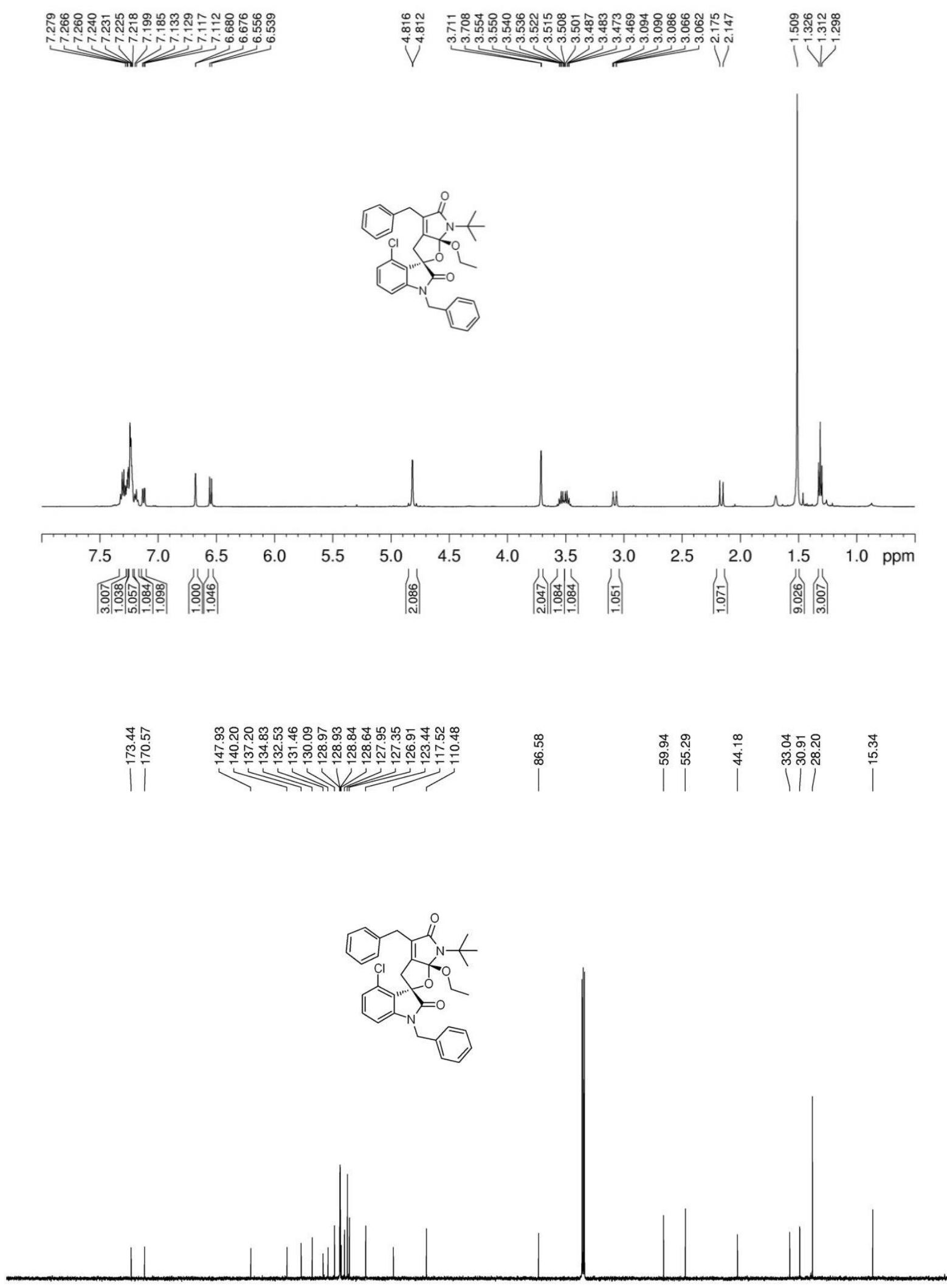

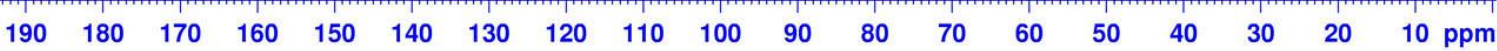




\section{Compound $6 f$}

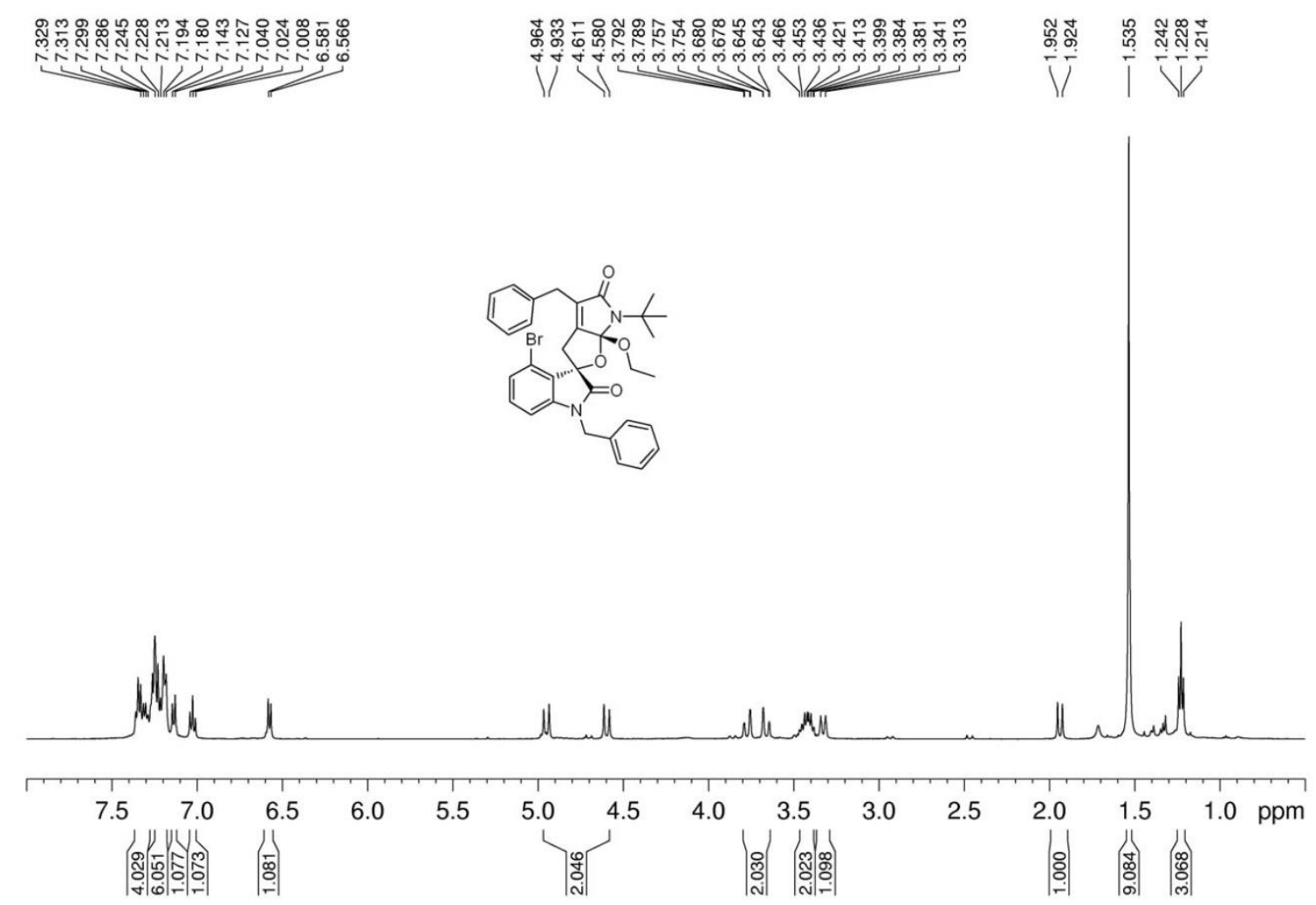

$\left.\right|_{\mid} ^{\mid}$
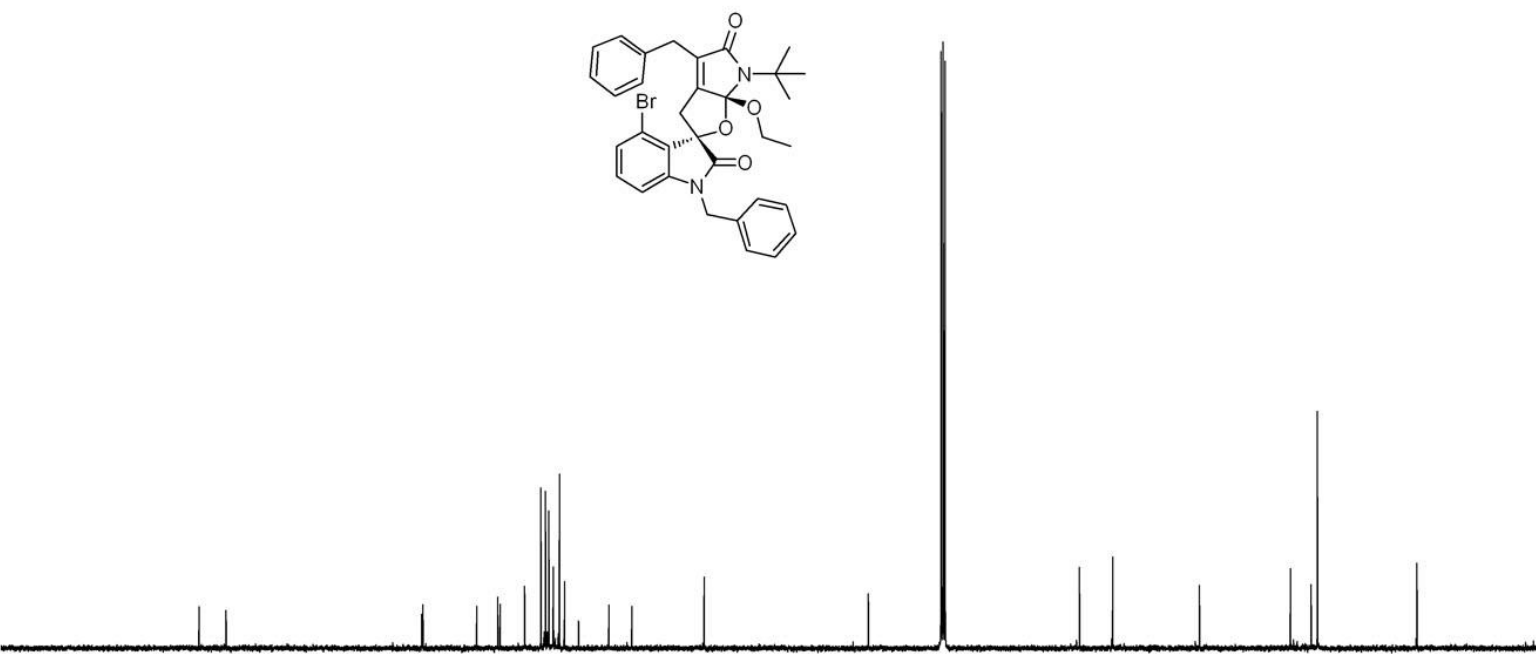

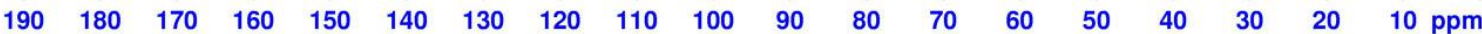




\section{Compound $\mathbf{6 g}$}
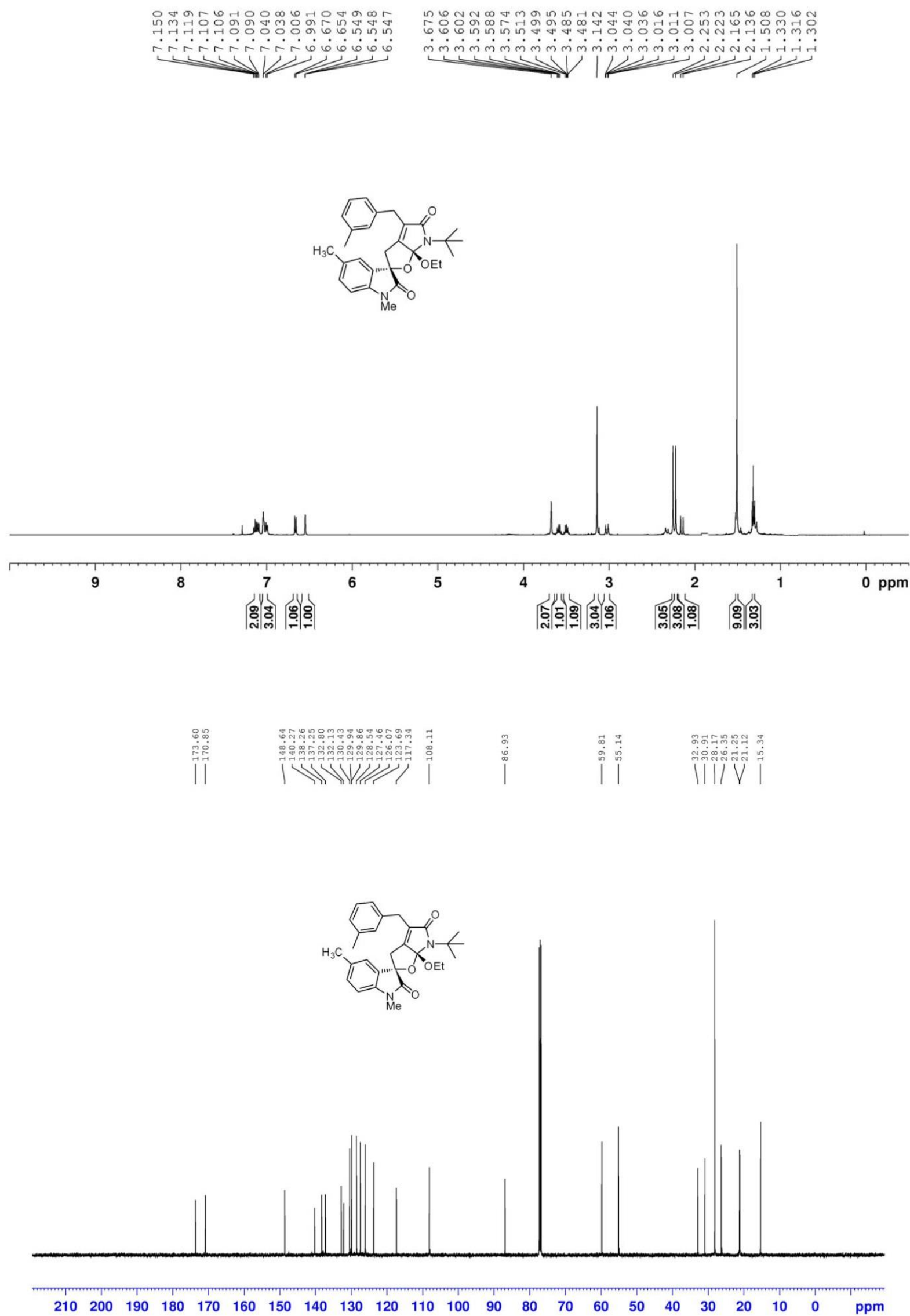


\section{Compound $\mathbf{6 h}$}
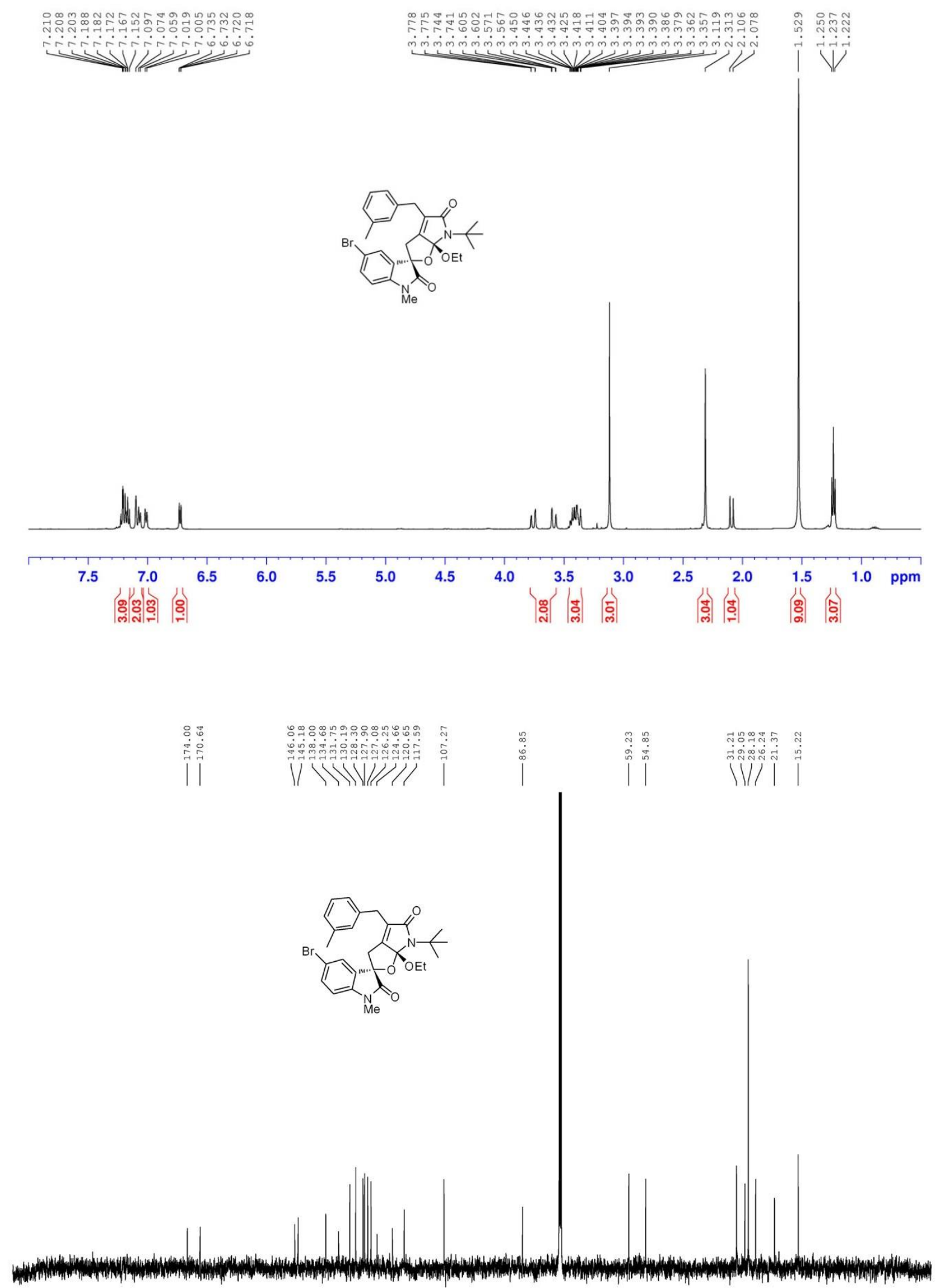

$\begin{array}{lllllllllllllllllllllll}210 & 200 & 190 & 180 & 170 & 160 & 150 & 140 & 130 & 120 & 110 & 100 & 90 & 80 & 70 & 60 & 50 & 40 & 30 & 20 & 10 & 0 & \mathrm{ppm}\end{array}$ 


\section{Compound 7a}

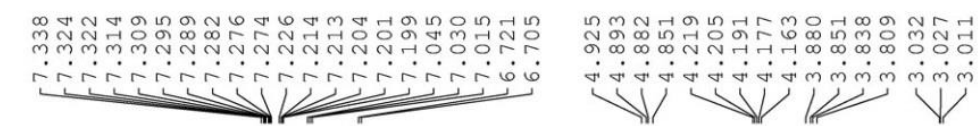

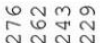

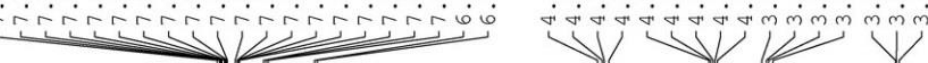
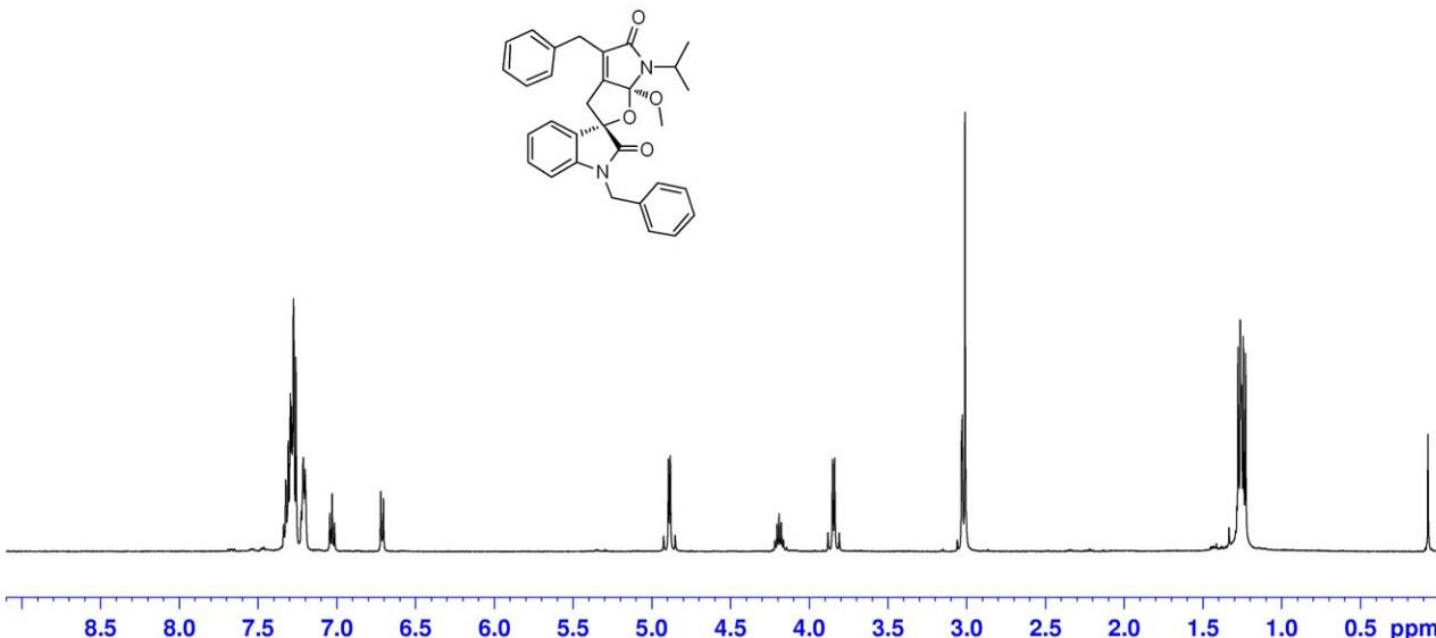

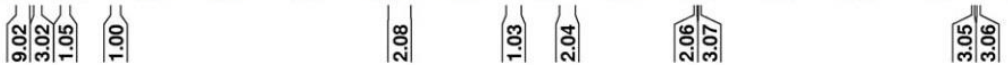

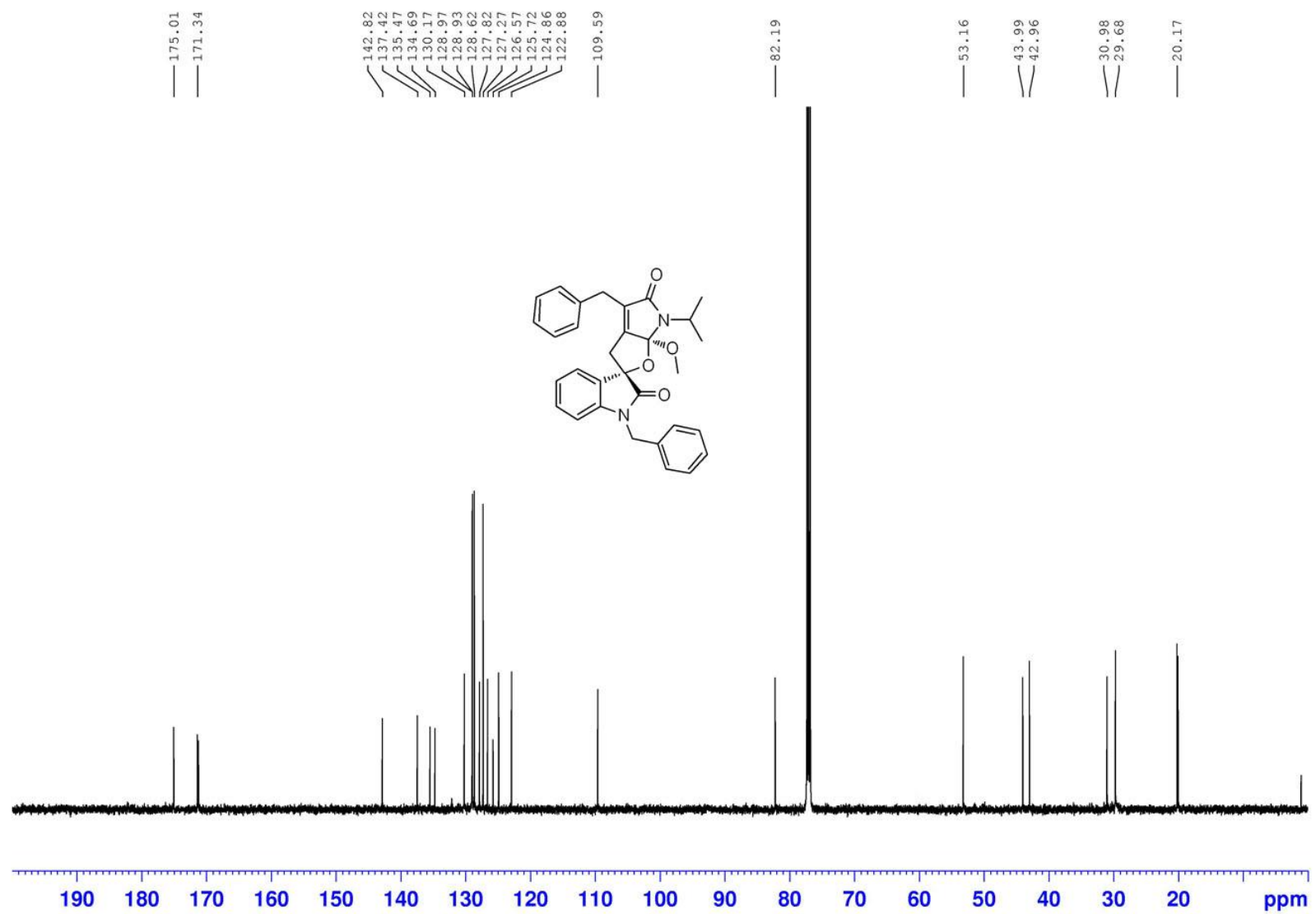




\section{Compound 7b}

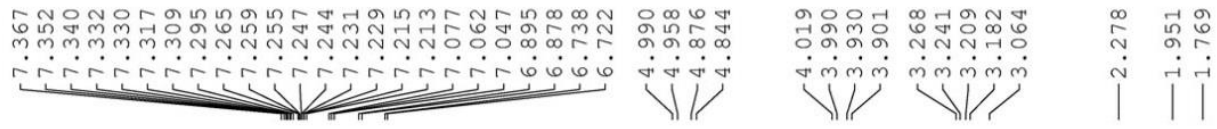
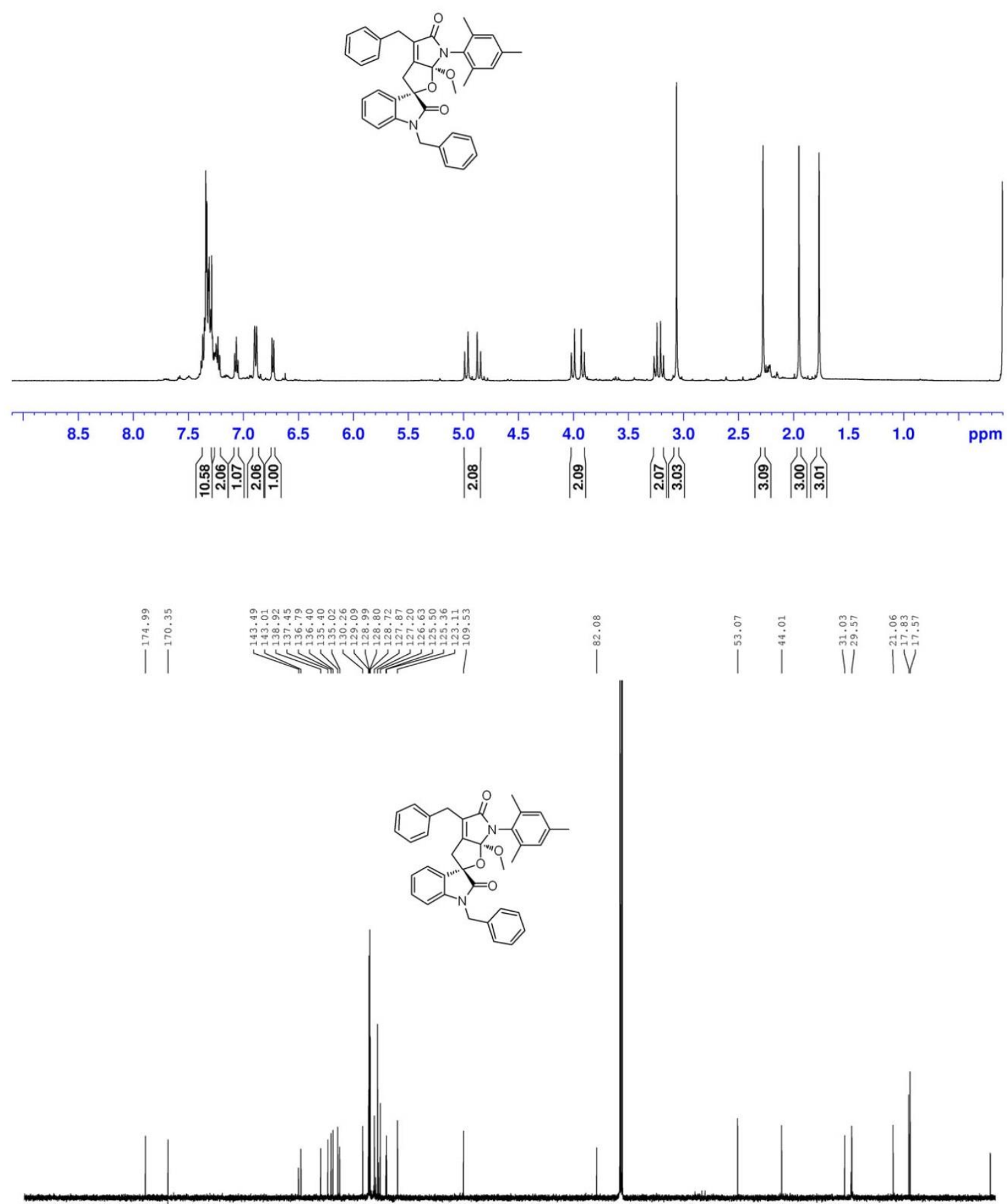

$\begin{array}{lllllllllllllllllll}190 & 180 & 170 & 160 & 150 & 140 & 130 & 120 & 110 & 100 & 90 & 80 & 70 & 60 & 50 & 40 & 30 & 20 & \mathrm{ppm}\end{array}$ 


\section{Compound 8a}

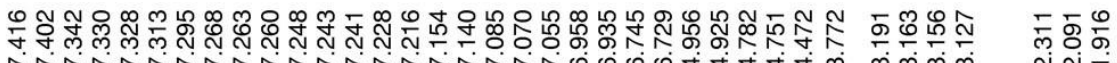

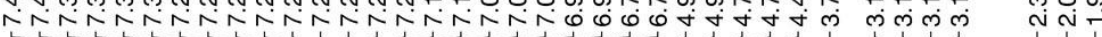

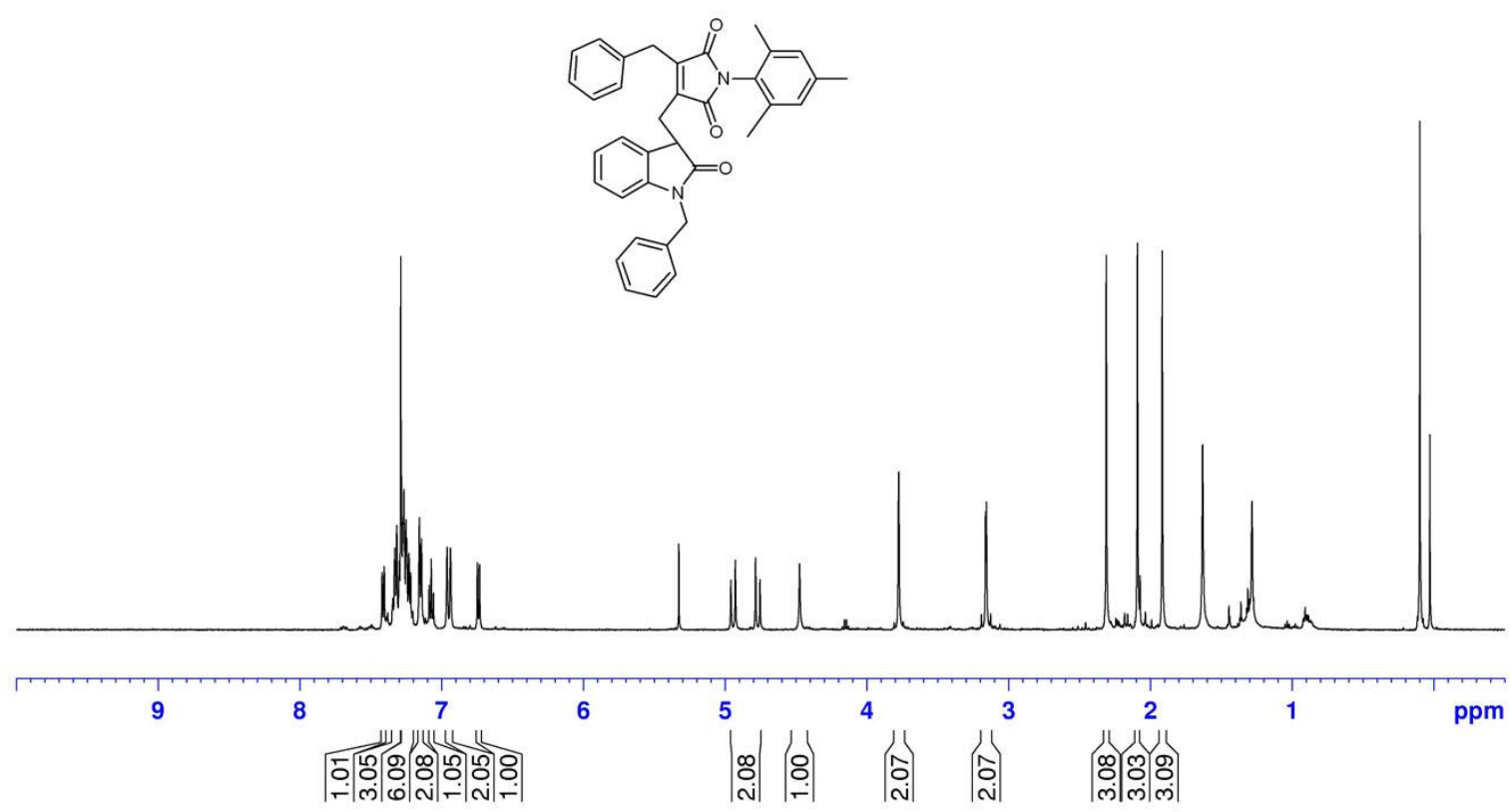

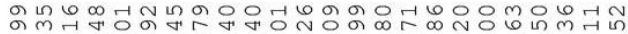

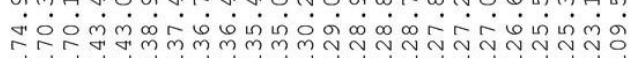

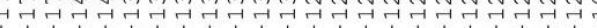

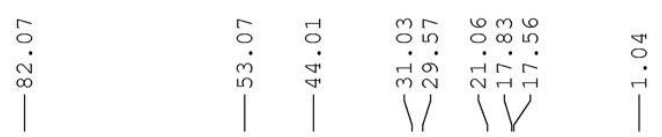
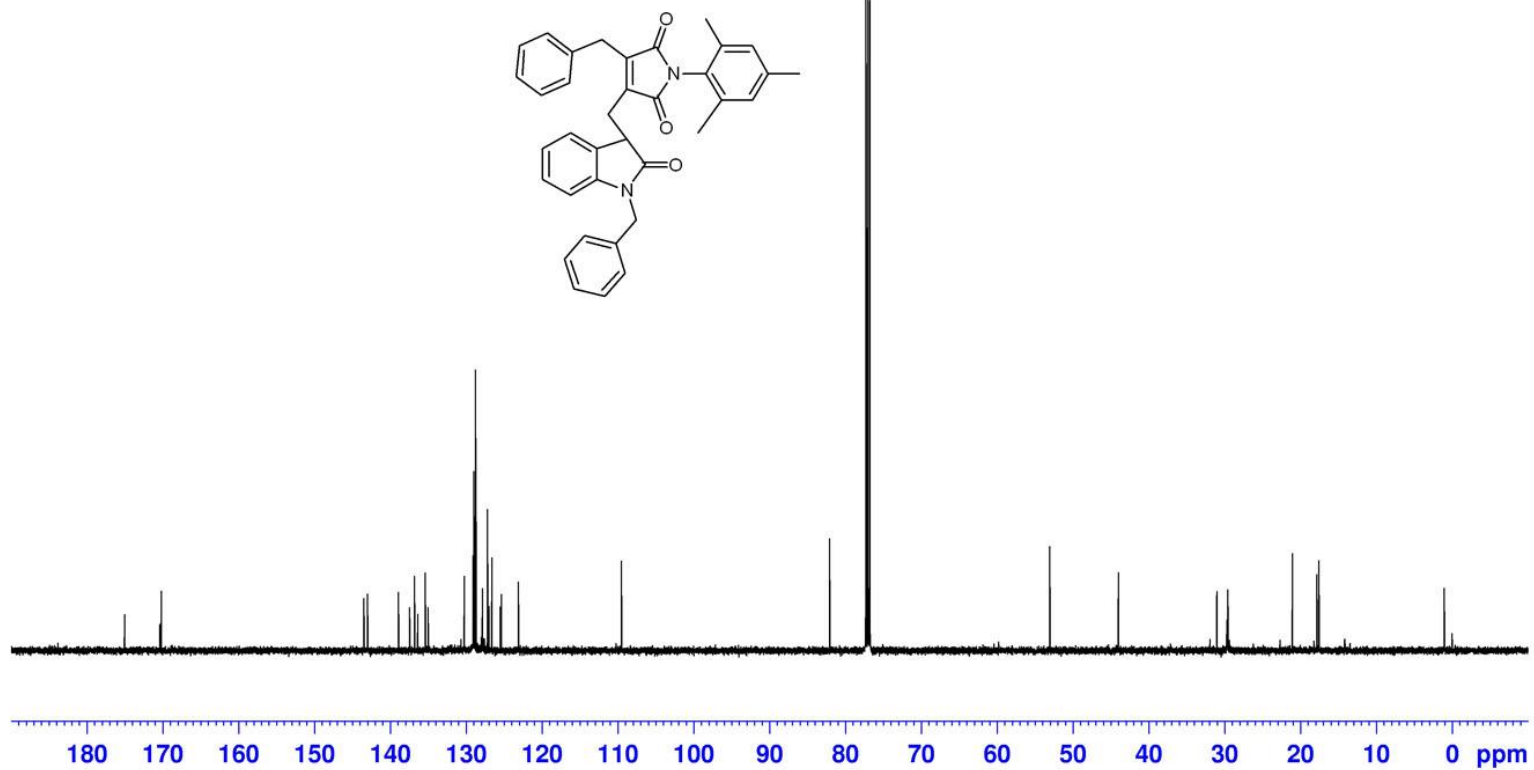


\section{Compound 9a}
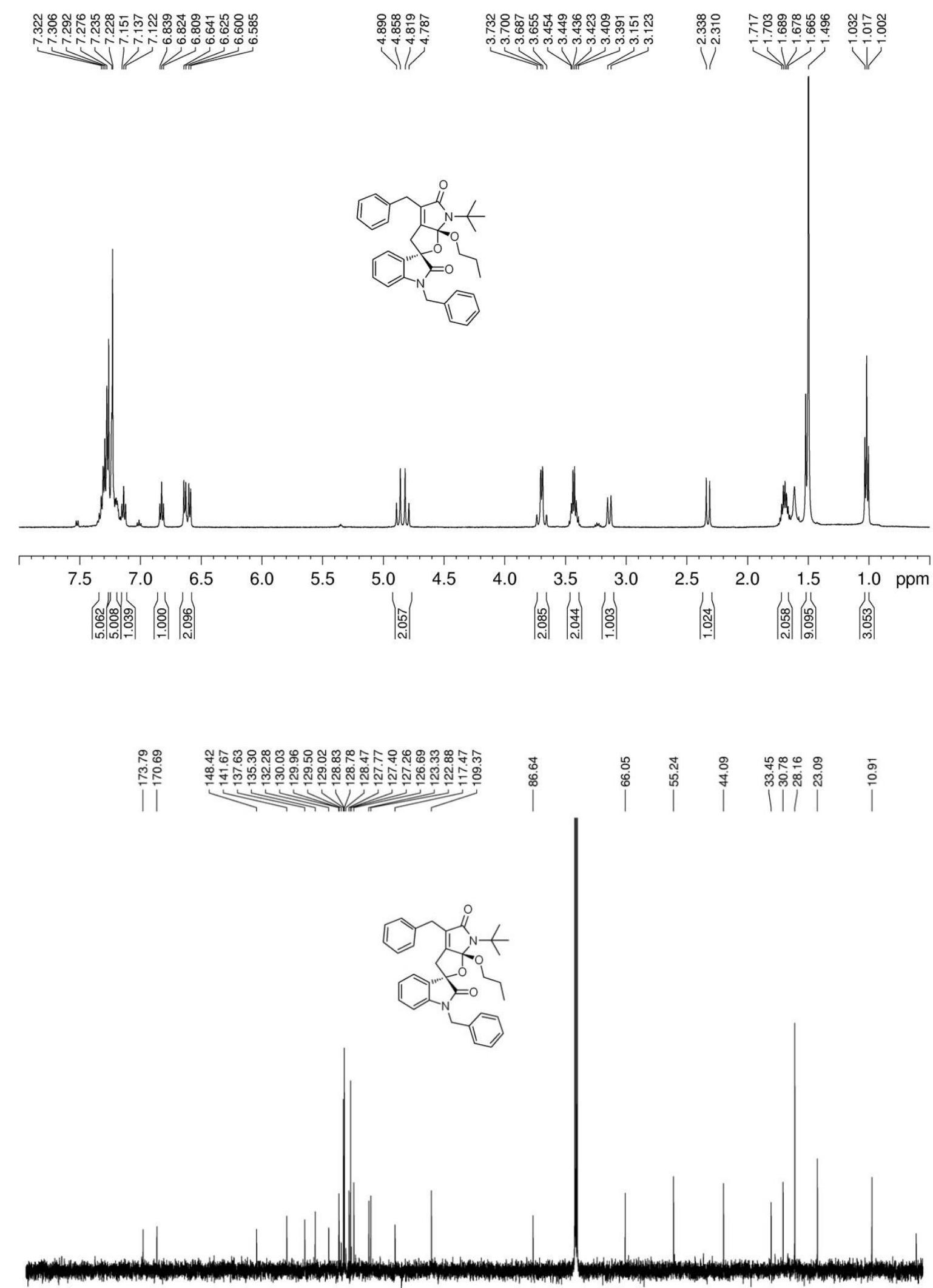

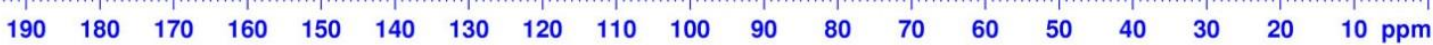




\section{Crystal Structure of Compound $4 d$}

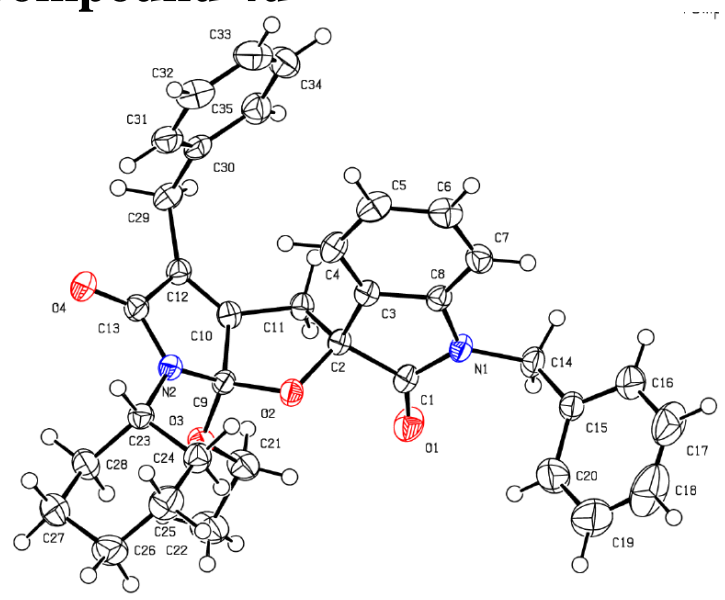

Figure 1 Single Crystal X-Ray structure for $\mathbf{4 d}$ (30\% probability thermal ellipsoids)

Table 1 Crystal data and structure refinement for $\mathbf{4 d}$

Empirical formula

Formula weight

Temperature

Wavelength

Crystal system, space group

Unit cell dimensions

Volume

Z, Calculated density

Absorption coefficient

$\mathrm{F}(000)$

Crystal size

Theta range for data collection

Limiting indices

Reflections collected / unique

Completeness to theta $=27.501$

Absorption correction

Max. and min. transmission

Refinement method

Data / restraints / parameters

Goodness-of-fit on $\mathrm{F}^{\wedge} 2$

Final R indices [I>2sigma(I)]

Largest diff. peak and hole

\section{C35 H36 N2 O4}

548. 66

$203 \mathrm{~K}$

$0.71073 \AA$

monoclinic

$\mathrm{a}=8.5520(12) \AA \quad$ alpha $=90^{\circ}$.

$\mathrm{b}=28.963(4) \AA \quad$ beta $=109.547(2)^{\circ}$.

$\mathrm{c}=12.2072(18) \AA$ gamma $=90^{\circ}$.

2849.4(7) $\AA^{3}$

4, $1.279 \mathrm{Mg} / \mathrm{m}^{3}$

$0.075 \mathrm{~mm}^{-1}$

1168

$0.22 \times 0.20 \times 0.16 \mathrm{~mm}$

0.990 to $27.501^{\circ}$

$-10<=\mathrm{h}<=11,-37<=\mathrm{k}<=37,-15<=\mathrm{l}<=15$

$6468 / 4796$ [R(int) $=0.0142]$

$98.2 \%$

None

0.9881 and 0.9836

Full-matrix least-squares on $\mathrm{F}^{2}$

4229 / 0 / 301

1.032

$\mathrm{R} 1=0.0579, \mathrm{wR} 2=0.1891$

0.141 and -0.175 e. $\AA^{-3}$ 